Archive for

Organic Chemistry

Arkivoc 2018, part vi, 314-347

\title{
An update on the synthesis and reactivity of spiro-fused $\beta$-lactams
}

\author{
Hang Dao Thi and Matthias D'hooghe* \\ SynBioC Research Group, Department of Green Chemistry and Technology, Faculty of Bioscience Engineering, \\ Ghent University, Coupure Links 653, B-9000 Ghent, Belgium \\ Email: matthias.dhooghe@UGent.be
}

Received 11-08-2018

Accepted 12-17-2018

Published on line 03-30-2019

\section{Abstract}

$\beta$-Lactam ring-containing compounds play a pivotal role in drug design and synthetic chemistry. Spirocyclic $\beta$ lactams, representing an important $\beta$-lactam subclass, have recently attracted considerable interest with respect to new synthetic methodologies and pharmacological applications. The aim of this manuscript is to review the recent progress made in this field, covering publications disseminated between 2011 to 2018 concerning the synthesis and application of spirocyclic $\beta$-lactams. In the first part, new approaches to the synthesis of spirocyclic $\beta$-lactams, including Staudinger synthesis, cyclization and transformation reactions, will be presented. The reactivity and biological properties of spiro- $\beta$-lactams will be described in the second and third part, respectively.
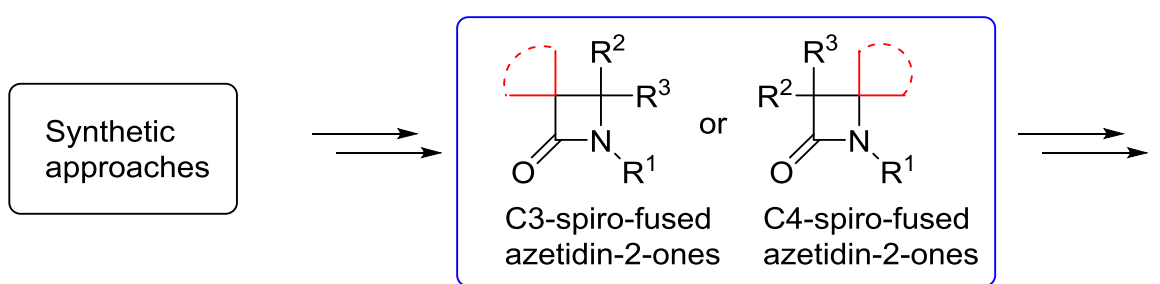

\section{Synthetic applications}

Keywords: $\beta$-Lactams, spiroazetidin-2-ones, spiro- $\beta$-lactams, fused rings 


\section{Table of Contents}

1. Introduction

2. Synthesis of Spiro-fused $\beta$-lactams

2.1. Cyclocondensation reactions

2.1.1. Reactions of acyclic ketenes

2.1.2. Reactions of cyclic ketenes

2.2. Cyclization reactions

2.3. Transformations of substituents connected to monocyclic azetidin-2-ones

2.4. Other methods

3. Reactivity of Spiro-fused $\beta$-lactams

3.1. Ring-opening reactions

3.2. Ring-transformation reactions of substituents attached to the ring carbon atoms

4. Bioactive Spiro-fused $\beta$-lactams

5. Conclusions

References

Author's Biographies

\section{Introduction}

The $\beta$-lactam (azetidin-2-one) ring is one of the most significant azaheterocycles studied from both a synthetic and medicinal chemistry point of view in the last decades. Its prominence is due to the presence of the $\beta$-lactam core in many antibiotics (e.g., penicillins, carbapenems, monobactams and sulbactams) used in the fight against pathogenic bacteria. In addition to their antibacterial properties, $\beta$-lactams possess other pharmacological activities such as cholesterol absorption inhibition, anti-inflammation, anti-tubercular and anti-HIV activity. ${ }^{1}$ Over the years, $\beta$-lactams have also emerged as versatile building blocks ( $\beta$-lactam synthon method) for the synthesis of amino acids, alkaloids and taxoids with potential biological properties. ${ }^{2-5}$ In the light of these excellent applications, much attention has been devoted to development of novel and more effective $\beta$-lactam compounds and the evaluation of their biological and synthetic potential. ${ }^{1,6}$ On the other hand, the overuse of $\beta$-lactam antibiotics leads to an increasing number of resistant bacterial strains. These new challenges have given impetus to the search for the replacement or modification of the available $\beta$ lactam structures to meet current urgent needs. ${ }^{7-9}$

Spirocyclic $\beta$-lactams, which contain a (small) ring spiro-fused at the C3 or C4 position of a $\beta$-lactam core (Figure 1), have recently been found to be eligible candidates for drug discovery. They have, for example, been exploited as antibacterial agents, antiviral agents and cholesterol absorption inhibitors. In that respect, structure-activity relationship studies have identified 3-spiro-cyclohexyl- $\beta$-lactams SCH $54016 \mathrm{~A}$ and SCH $58053 \mathrm{~B}$ as two potential cholesterol absorption inhibitors. ${ }^{10}$ In addition, spiro- $\beta$-lactams have been used as $\beta$ turn mimetics in peptidomimetic chemistry. It has been found that spiro- $\beta$-lactams also act as poliovirus and human rhinovirus $3 C$-proteinases inhibitors. Thus, the search for new spiro- $\beta$-lactam derivatives comprises a relevant research topic. ${ }^{10}$ In addition, spiro- $\beta$-lactams have been used as starting materials to prepare $\alpha$ - and $\beta$-amino acids, alkaloids, heterocycles, taxoids ${ }^{11}$ and other relevant compounds. ${ }^{12}$ In that respect, several new methodologies for the synthesis of spiro- $\beta$-lactams have been developed, as is evident from the many reviews in the field. ${ }^{11-13}$ 
As an extension of the review article by De Kimpe in 2011, this review is constructed in a similar way, including synthetic approaches, reactivity, and biological activities of spiro-fused azetidin-2-ones, spanning publications from 2011 to $2018 .{ }^{13}$

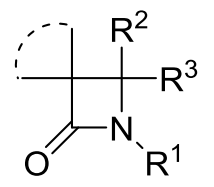

C3-spiro-fused azetidin-2-ones

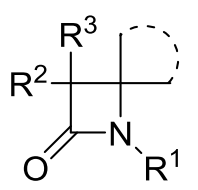

C4-spiro-fused azetidin-2-ones

Figure 1. General representation of C3 and C4 spiro-fused azetidin-2-ones.

\section{Synthesis of Spiro-fused $\beta$-lactams}

\subsection{Cyclocondensation reactions}

The Staudinger [2+2]-cyclocondensation of ketenes and imines is the most widely used method for the synthesis of the $\beta$-lactam ring skeleton. Although, according to IUPAC guidelines, the term 'cycloaddition' can be used for this two-step process via zwitterionic intermediates, this method is mostly referred to as a cyclocondensation reaction. Spiro-fused $\beta$-lactams can also be prepared in this way employing various types of ketenes and imines. Depending on the ketenes and imines applied, two different types of spiro-fused azetidin2-ones can be synthesized. More specifically, the reaction of an acyclic ketene with a cyclic imine will furnish C4 spiro-fused azetidin-2-ones, whereas the reaction of a cyclic ketene with an acyclic imine will afford C3 spiro-fused azetidin-2-ones.

2.1.1. Reactions of acyclic ketenes. Jarrahpour and co-workers have explored the potential of the Staudinger synthesis to access new spiro-fused $\beta$-lactams. In particular, the [2+2]-cyclocondensation of imines 1 , which were prepared from $9 H$-fluoren-9-one and substituted anilines with a catalytic amount of acetic acid in ethanol, with either phenoxyacetic acid or $9 H$-xanthene-9-carboxylic acid in the presence of triethylamine and tosyl chloride afforded spiro- $\beta$-lactams 2 or dispiro- $\beta$-lactams $\mathbf{3}$, respectively (Scheme 1$)$. This strategy has also been extended to the synthesis of several bis-spiro- and bis-dispiro- $\beta$-lactams. ${ }^{6,14}$ The spiro- $\beta$-lactams 3 could be further converted into the corresponding $\mathrm{NH}$-spiro- $\beta$-lactams in excellent yields by eluting them over a column packed with $10 \% \mathrm{SiO}_{2}-\mathrm{NaSO}_{3}, 10 \% \mathrm{CAN}-\mathrm{SiO}_{2}$ and little silica gel. ${ }^{15}$

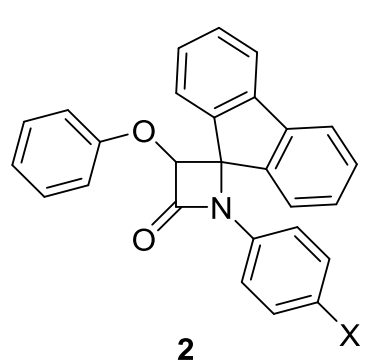

2

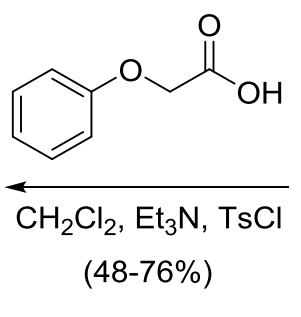

$\mathrm{X}=\mathrm{CH}_{3}, \mathrm{OCH}_{3}, \mathrm{Cl}$

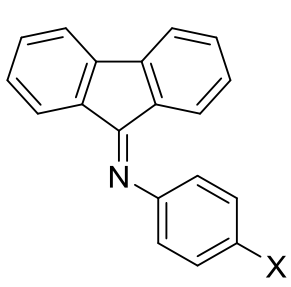

1

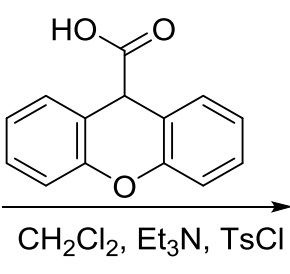

(55-83\%)

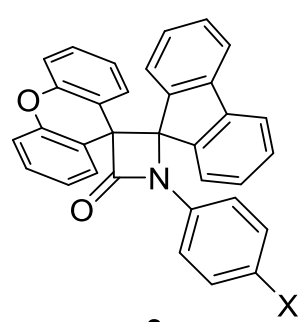

3

\section{Scheme 1}


The spirocyclic indeno[1,2-b]quinoxaline $\beta$-lactams 5 and 6 were prepared by treatment of $N$-phenyl-11Hindeno[1,2-b]quinoxalin-11-imine derivatives 4 with various phenoxyacetic acid derivatives in the presence of triethylamine and tosyl chloride in anhydrous $\mathrm{CH}_{2} \mathrm{Cl}_{2}$ at room temperature (Scheme 2). The diastereomeric ratio of 5 and 6 (50:50) was determined by the integration of the proton $\mathrm{H}-3$. The structures of $\beta$-lactams 5 and 6 were further confirmed by X-ray crystallography. ${ }^{16}$

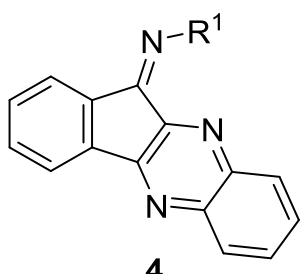

4

$$
\begin{aligned}
\mathrm{R}^{1}= & 4-\mathrm{MeOC}_{6} \mathrm{H}_{4} \\
& 4-\mathrm{MeC}_{6} \mathrm{H}_{4} \\
& 4-\mathrm{iPrC}_{6} \mathrm{H}_{4} \\
& \text { 3,4-(MeO })_{2} \mathrm{C}_{6} \mathrm{H}_{3}
\end{aligned}
$$

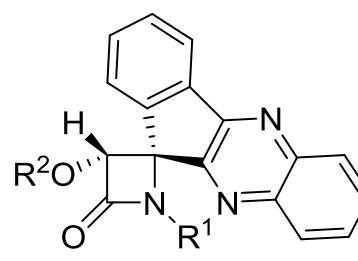

5

50

$\mathrm{R}^{2}=\mathrm{C}_{6} \mathrm{H}_{5}$

4- $\mathrm{ClC}_{6} \mathrm{H}_{4}$

$2,4-\mathrm{Cl}_{2} \mathrm{C}_{6} \mathrm{H}_{3}$

\section{Scheme 2}

The synthesis and pharmacological evaluation of isatin-derived compounds has attracted the attention of many research groups. ${ }^{13,17-20}$ For example, in the course of a screening study for $\beta$-lactam compounds possessing antibacterial and antifungal activities, Shah and co-workers successfully synthesized a number of novel spiro[azetidine-2,3'-indole]-2',4(1'H)-diones 10 and 12 by means of the Staudinger synthesis (Scheme 3 ). The preparation of imines $\mathbf{9}$ and $\mathbf{1 1}$ was performed by reaction between either dibromoisatin $\mathbf{8}$, which was obtained by treatment of isatin $\mathbf{7}$ with bromine in methanol, or isatin $\mathbf{7}$ with different primary aromatic amines in absolute ethanol in the presence of glacial acetic acid. Subsequently, treatment of imines $\mathbf{9}$ and $\mathbf{1 1}$ with chloroacetyl chloride in the presence of a tertiary base at $80^{\circ} \mathrm{C}$ to reflux temperature led to the target spiro- $\beta$ lactams 10 and 12. The antibacterial and antifungal activities of these spiro $\beta$-lactams were evaluated. ${ }^{21}$

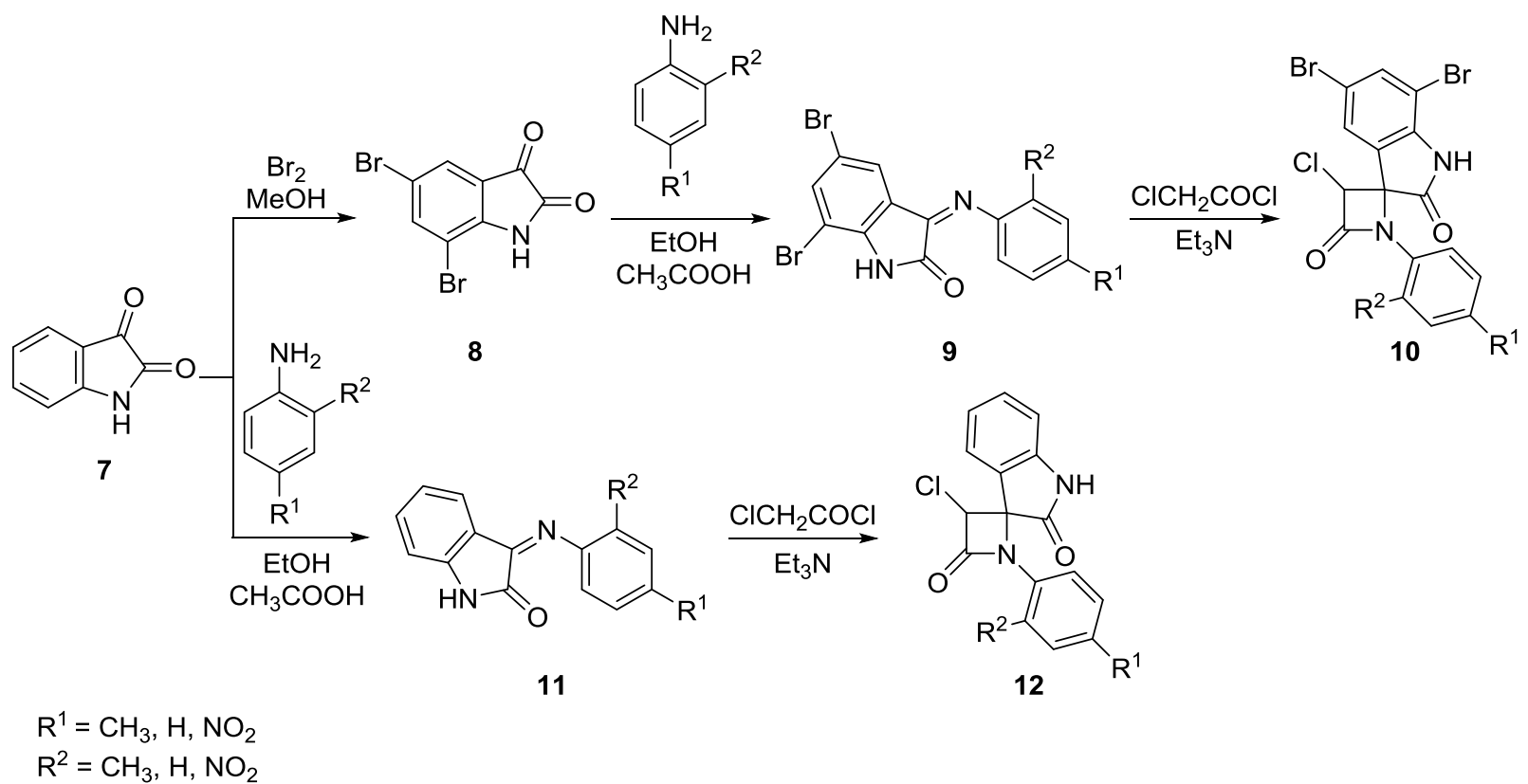

\section{Scheme 3}


In addition, the cyclocondensation of isatin-3-arylimine with various diazoketo esters catalyzed by rhodium(II) also gave rise to spiro(oxindolyl)- $\beta$-lactams. ${ }^{22}$ Recently, the Kandile group has reported the generation of bis-spiroazetidinone derivatives by the reaction of bis-Schiff bases, derived from 5-substituted isatins, with chloroacetyl chloride. ${ }^{23}$ Concurrently, $\mathrm{Xu}$ and co-workers have disclosed a direct asymmetric $[2+2]$-annulation reaction of simple aliphatic aldehydes with isatin-derived ketimines via $\mathrm{N}$-heterocyclic carbene (NHC) catalysis furnishing enantioenriched spiroindole $\beta$-lactams. ${ }^{24}$

The synthesis of spiro-fused seleno- $\beta$-lactams has been studied by using $Z / E$ isomers of $\alpha$-seleniumsubstituted exocyclic imines $\mathbf{1 3}$ with various types of acyl chlorides, such as methoxy-, chloro-, propionyl-, phenyl-, cyclohexyl-, phenoxy-, and p-chlorophenoxyacetyl chloride under optimized Staudinger synthesis conditions (Scheme 4). The reaction of exocyclic imines 13 with acetyl chlorides 14 gave rise to spiro- $\beta$-lactams 15 in excellent yields as mixtures of stereoisomers. The diastereomeric ratio (d.r.) of the resulting spiro- $\beta$ lactams 15 was calculated by ${ }^{1} \mathrm{H}$ NMR spectral analysis. It should be noted that the stereochemical outcome of $\beta$-lactam formation under Staudinger reaction conditions can be explained by the electronic effects of the substituents on the ketenes, which were generated from the corresponding acid chlorides. ${ }^{25}$

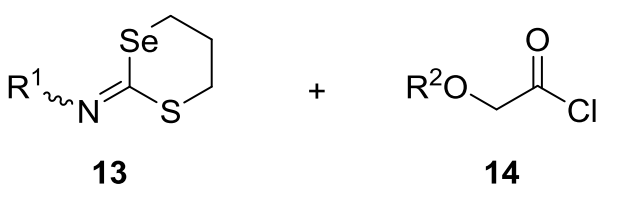

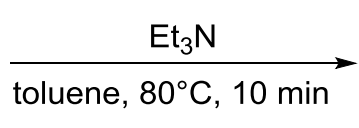

$\mathrm{R}^{1}=\mathrm{C}_{6} \mathrm{H}_{5}, \mathrm{R}^{2}=\mathrm{Me}, 98 \%$, d.r. $=73: 27$

$\mathrm{R}^{1}=p-\mathrm{MeC}_{6} \mathrm{H}_{4}, \mathrm{R}^{2}=\mathrm{Me}, 95 \%$, d.r. $=71: 29$

$\mathrm{R}^{1}=0-\mathrm{MeC}_{6} \mathrm{H}_{4}, \mathrm{R}^{2}=\mathrm{Me}, 97 \%$, d.r. $=73: 27$

$\mathrm{R}^{1}=p-\mathrm{ClC}_{6} \mathrm{H}_{4}, \mathrm{R}^{2}=\mathrm{Me}, 88 \%$, d.r. $=73: 27$

$\mathrm{R}^{1}=p-\mathrm{MeOC}_{6} \mathrm{H}_{4}, \mathrm{R}^{2}=\mathrm{Me}, 99 \%$, d.r. $=69: 31$

$\mathrm{R}^{1}=$ 2-Napthyl, $\mathrm{R}^{2}=\mathrm{Me}, 93 \%$, d.r. $=72: 28$

$\mathrm{R}^{1}=\mathrm{C}_{6} \mathrm{H}_{5} \mathrm{CH}_{2}, \mathrm{R}^{2}=\mathrm{Me}, 98 \%$, d.r. $=80: 20$

$\mathrm{R}^{1}=$ Cyclohexyl, $\mathrm{R}^{2}=\mathrm{Me}, 98 \%$, d.r. $=78: 22$

$\mathrm{R}^{1}=\mathrm{C}_{6} \mathrm{H}_{5}, \mathrm{R}^{2}=p-\mathrm{ClC}_{6} \mathrm{H}_{4}, 89 \%$, d.r. $=71: 29$

\section{Scheme 4}

The synthesis of new spiro-fused azetidinone-androgen derivative 19 began with the conversion of $17 b$ [(tert-butyldimethylsilyl)oxy]androst-4-en-3-one $\mathbf{1 6}$ to Schiff's base $\mathbf{1 7}$ using boric acid as a catalyst (Scheme 5). The treatment of compound $\mathbf{1 7}$ with dihydrotestosterone afforded thiourea $\mathbf{1 8}$. The later compound 18 was further converted into the desired bis-spiro steroidal $\beta$-lactam 19 by treatment with chloroacetyl chloride in the presence of triethylamine. The Staudinger-based synthesis of androgen derivative 19 constitutes a straightforward procedure in comparison with other methodologies applied in the synthesis of steroid derivatives. ${ }^{26}$ 
<smiles>CC12CCC3C(CCC(O[Si](C)(C)C(C)(C)C)C31C)C1CCC3=CC(=O)CC[C@]31C2</smiles>

16

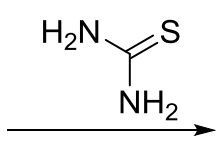

Boric acid (cat) (85\%)<smiles>[Z7]CC1=CC(=NC(N)=S)CCC12CCC[C@]1(C)C(O[Si](C)(C)C(C)(C)C)CCC21</smiles>

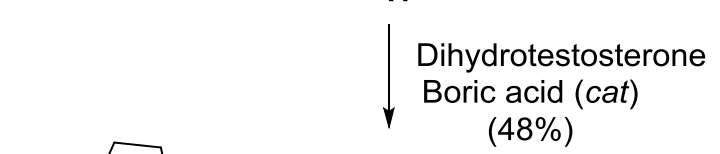<smiles>C[C@]12CCC(=N)CC1CCC1C3CCC4C(O)C(O)CC[C@]4(C)C3CCC12</smiles>
$(48 \%)$

$(48 \%)$<smiles>CCCO[Si](C)(C)C(C)(C)C</smiles>

18<smiles>CCNC(=O)CCl</smiles>

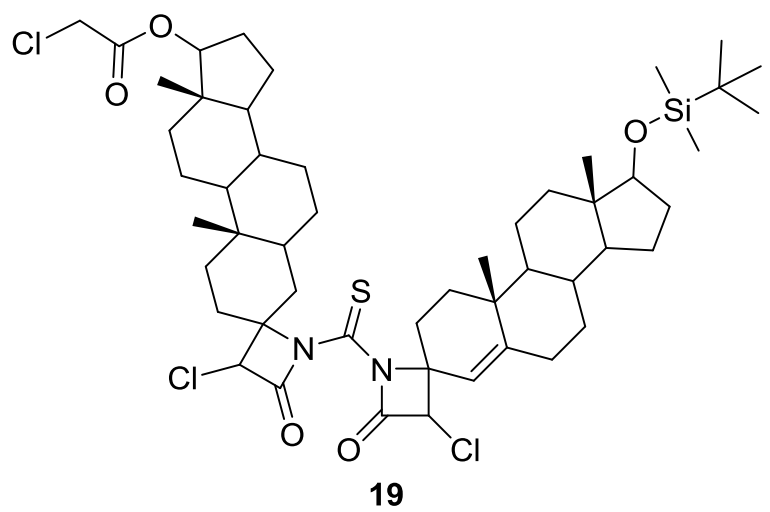

\section{Scheme 5}

The reaction of imines $\mathbf{2 3}$ with chloroacetyl chloride in dimethylformamide yielded the corresponding spiro-fused $\beta$-lactam derivatives 24 (Scheme 6). The required imines $\mathbf{2 3}$ were prepared by condensation of bicycle 22 with nitroso derivatives in dimethylformamide in the presence of piperidine as a catalyst. In turn, bicycle 22 was synthesized from 4-acetyl-5-amino-3-methyl-1-phenyl-2-pyrazoline $\mathbf{2 1}$ by an intramolecular Mannich reaction. Pyrazoline 21 was derived from 4-acetyl-5-imino-3-methyl-1-phenyl-2-pyrazoline 20 by a reductive reaction using $\mathrm{Zn} / \mathrm{AcOH}^{27}$

Anand and co-workers ${ }^{28}$ have reported the facile synthesis of axial and equatorial spiro- $\beta$-lactams 26 via the entrapment of cyclohexanone imines 25 with acetoxyacetyl chloride in a [2+2]-cyclocondensation at $-78^{\circ} \mathrm{C}$ (Scheme 7). The resulting conformations of 4-substituted 1-azaspiro[3.5]nonan-2-ones 26, which could be isolated as stable, pure crystals, were confirmed by X-ray crystallography. The restricted conformers were kinetically resolved using lipases. The mechanism of spiro- $\beta$-lactam 26 formation was explored using B3LYP/6$31+G^{*}$ level quantum chemical calculations. ${ }^{28}$ 
<smiles>CC(=O)c1c(C)nn(-c2ccccc2)c1N</smiles>

20<smiles>CC(=O)C1C(C)=NN(c2ccccc2)C1N</smiles>

21

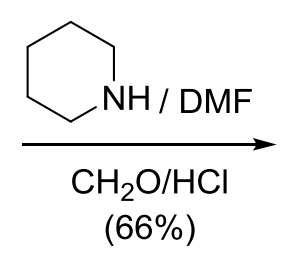

(66\%)<smiles>CC1=NN(c2ccccc2)C2NCCC(=O)C12</smiles>

22

RNO

DMF/pip

$\checkmark(40-98 \%)$<smiles>[R]N1C(=O)C(Cl)C12CNC1C(C(=O)N(C)OCC)C(C)=NN1c1ccccc12</smiles>

24<smiles>[R]N=C1CNC2C(C1=O)C(C)=NN2c1ccccc1</smiles>

23<smiles>[R]=Cc1ccc(N(C)C)cc1</smiles>

\section{Scheme 6}

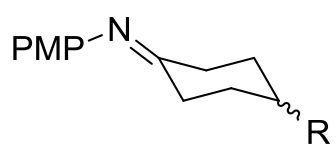

25

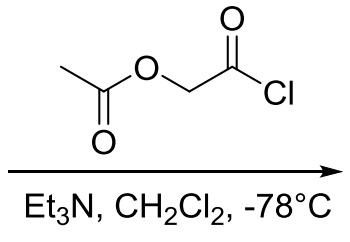

(75-93\%)

$\mathrm{R}=\mathrm{Me}, \mathrm{Et}, t-\mathrm{Bu}$

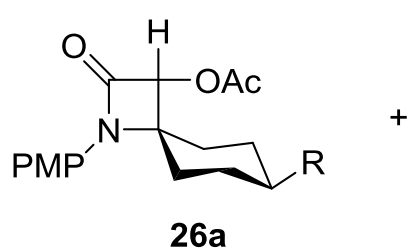

$26 a$

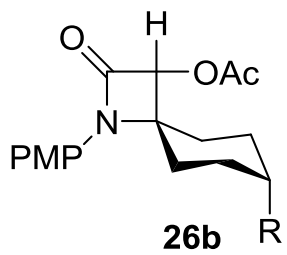

26b R

\section{Scheme 7}

Imines 27, derived from 8-azabicyclo[3.2.1]octan-3-ones, have been shown to be interesting starting materials for the synthesis of a new class of $\beta$-lactams $\mathbf{2 8}$ via Staudinger synthesis with phenoxyacetyl chloride (Scheme 8). It is noteworthy that the stereochemical outcome of the obtained spiro- $\beta$-lactams (as single diastereoisomers) was opposite to the expected products of a [2+2]-cycloaddition reaction, which should have taken place from the exo face of compound $27 .^{29}$

The Reddy group ${ }^{30}$ has reported on the synthesis and biological evaluation of a novel series of spiroazetidin-2-ones $\mathbf{3 3}$ starting from 3-chloro-4-fluoroaniline $\mathbf{2 9}$ (Scheme 9). Firstly, the benzothiazole $\mathbf{3 0}$ was synthesized from 3-chloro-4-fluoroaniline 29 and further condensed with 5-methyl-2-phenylpyrazol-3-one to yield the imine 31, which was cyclized with chloroacetyl choride in triethylamine to obtain azetidin-2-one 32. Finally, the resulting azetidin-2-one $\mathbf{3 2}$ was further condensed with different primary and secondary amines, leading to the desired spiro-fused $\beta$-lactams 33. These $\beta$-lactams $\mathbf{3 3}$ exhibited moderate to significant activities in anti-inflammatory, anti-diabetic, anti-oxidant and anti-microbial tests. ${ }^{30}$ 


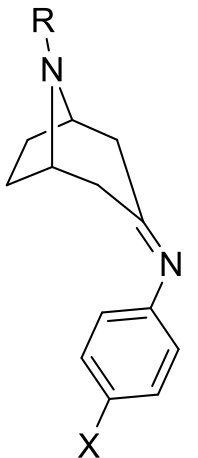

27<smiles>CCOCCOc1ccccc1</smiles>

$(30-91 \%)$<smiles>[X]c1ccc(N2C(=O)C(Oc3ccccc3)C23CC2CCC(C2)N3[R])cc1</smiles>

28<smiles>[Y]=C=[V]</smiles>

\section{Scheme 8}<smiles>Nc1ccc(F)c(Cl)c1</smiles>

29
$\underset{\mathrm{Br}_{2}, \mathrm{NH}_{3}}{\stackrel{\mathrm{KSCN}, \mathrm{CH}_{3} \mathrm{COOH}}{\longrightarrow}}$<smiles>Nc1nc2ccc(F)c(Cl)c2s1</smiles>

30<smiles>CC1=NN(c2ccccc2)C(=O)C1</smiles><smiles>CCCCCCN1N=C(C)CC1=Nc1nc2ccc(F)c(Cl)c2s1</smiles>

31

$\mathrm{R}^{1} \mathrm{R}^{2} \mathrm{NH}=0$-Anisidine, $m$-Anisidine p-Anisidine, o-Toluidine $m$-Toluidine, $p$-Toluidine ß-Phenylethylamine, Morpholine<smiles>[R]N([R])c1c(F)ccc2nc(N3C(=O)C(Cl)C34CC(C)=NN4C)sc12</smiles>

33<smiles>CC1=NN(C)C2(C1)C(Cl)C(=O)N2c1nc2ccc(F)c(Cl)c2s1</smiles>

32

\section{Scheme 9}

In an analogous approach, spiro-[chloroazetidinethiazolopyrimidine] derivatives were obtained by using the corresponding thiazolopyrimidine imines. ${ }^{31}$

2.1.2. Reactions of cyclic ketenes. The utilization of cyclic ketenes in the [2+2]-cyclocondensation with imines constitutes an alternative approach for the preparation of spiro- $\beta$-lactams. ${ }^{6,32-35}$ The generation of ketenes by the treatment of an acyl chloride with triethylamine is one of the most common methods; however, this 
approach has sometimes encountered disadvantages such as commercial unavailability, instability and difficulties related to the preparation of acid halides. ${ }^{36}$ To deal with these difficulties, the Zarei and Sardarian groups have independently devoted efforts to the preparation of a cyclic ketene from the corresponding xanthene-9-carboxylic acid $\mathbf{3 4}$ using different carboxylic activators $\mathbf{3 6}$ to synthesize spiro- $\beta$-lactams $\mathbf{3 7}$ by Staudinger reaction with imines 35 (Scheme 10, Table 1). ${ }^{15,36-43}$ The structure of 1-[3-(morpholin-4-yl)propyl]4-(3-nitrophenyl)spiro[azetidine-3,9'-xanthen]-2-one - an analog of spiro- $\beta$-lactams 37 - was successfully determined for the first time by Akkurt via single-crystal X-ray analysis. ${ }^{44}$

Table 1. Synthesis of spiro- $\beta$-lactams 37 using different carboxylic activators 36

\begin{tabular}{|c|c|}
\hline Compounds 36 & Compounds $37\left(R^{1}, R^{2}\right)$ \\
\hline & $\mathrm{R}^{1}=\mathrm{C}_{6} \mathrm{H}_{5}, \mathrm{R}^{2}=4-\mathrm{NO}_{2} \mathrm{C}_{6} \mathrm{H}_{4}, 82 \%$ \\
\hline & $\mathrm{R}^{1}=4-\mathrm{EtC}_{6} \mathrm{H}_{4}, \mathrm{R}^{2}=4-\mathrm{NO}_{2} \mathrm{C}_{6} \mathrm{H}_{4}, 87 \%$ \\
\hline 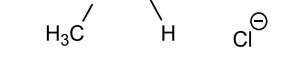 & $\mathrm{R}^{1}=4-\mathrm{MeOC}_{6} \mathrm{H}_{4}, \mathrm{R}^{2}=4-\mathrm{MeOC}_{6} \mathrm{H}_{4}, 85 \%$ \\
\hline & $\mathrm{R}^{1}=\mathrm{Me}, \mathrm{R}^{2}=4-\mathrm{MeOC}_{6} \mathrm{H}_{4}, 82 \%$ \\
\hline & $\mathrm{R}^{1}=\mathrm{C}_{6} \mathrm{H}_{5}, \mathrm{R}^{2}=4-\mathrm{ClC}_{6} \mathrm{H}_{4}, 87 \%$ \\
\hline & $\mathrm{R}^{1}=4-\mathrm{MeOC}_{6} \mathrm{H}_{4}, \mathrm{R}^{2}=4-\mathrm{ClC}_{6} \mathrm{H}_{4}, 85 \%$ \\
\hline & $\mathrm{R}^{1}=4-\mathrm{MeOC}_{6} \mathrm{H}_{4}, \mathrm{R}^{2}=4-\mathrm{MeOC}_{6} \mathrm{H}_{4}, 85 \%$ \\
\hline & $\mathrm{R}^{1}=4-\mathrm{EtOC}_{6} \mathrm{H}_{4}, \mathrm{R}^{2}=4-\mathrm{NO}_{2} \mathrm{C}_{6} \mathrm{H}_{4}, 81 \%$ \\
\hline & $\mathrm{R}^{1}=4-\mathrm{MeOC}_{6} \mathrm{H}_{4}, \mathrm{R}^{2}=4-\mathrm{MeOC}_{6} \mathrm{H}_{4}, 87 \%$ \\
\hline & $\mathrm{R}^{1}=4-\mathrm{MeOC}_{6} \mathrm{H}_{4}, \mathrm{R}^{2}=4-\mathrm{ClC}_{6} \mathrm{H}_{4}, 83 \%$ \\
\hline & $\mathrm{R}^{1}=4-\mathrm{MeOC}_{6} \mathrm{H}_{4}, \mathrm{R}^{2}=3,4,5-(\mathrm{MeO})_{3} \mathrm{C}_{6} \mathrm{H}_{2}, 80 \%$ \\
\hline & $\mathrm{R}^{1}=4-\mathrm{EtC}_{6} \mathrm{H}_{4}, \mathrm{R}^{2}=2,4-\mathrm{Cl}_{2} \mathrm{C}_{6} \mathrm{H}_{3}, 84 \%$ \\
\hline & $\mathrm{R}^{1}=4-\mathrm{MeOC}_{6} \mathrm{H}_{4}, \mathrm{R}^{2}=\mathrm{C}_{6} \mathrm{H}_{5}, 75 \%$ \\
\hline & $\mathrm{R}^{1}=4-\mathrm{ClC}_{6} \mathrm{H}_{4}, \mathrm{R}^{2}=4-(\mathrm{NMe}){ }_{2} \mathrm{C}_{6} \mathrm{H}_{3}, 71 \%$ \\
\hline & $\mathrm{R}^{1}=4-\mathrm{ClC}_{6} \mathrm{H}_{4}, \mathrm{R}^{2}=4-\mathrm{ClC}_{6} \mathrm{H}_{4}, 86 \%$ \\
\hline & $\mathrm{R}^{1}=4-\mathrm{ClC}_{6} \mathrm{H}_{4}, \mathrm{R}^{2}=4-\left(\mathrm{Me}_{2} \mathrm{CH}\right) \mathrm{C}_{6} \mathrm{H}_{4}, 87 \%$ \\
\hline & $\mathrm{R}^{1}=4-\mathrm{MeOC}_{6} \mathrm{H}_{4}, \mathrm{R}^{2}=2,4-\mathrm{Cl}_{2} \mathrm{C}_{6} \mathrm{H}_{3}, 72 \%$ \\
\hline & $\mathrm{R}^{1}=4-\mathrm{EtC}_{6} \mathrm{H}_{4}, \mathrm{R}^{2}=3,4,5-(\mathrm{MeO}){ }_{3} \mathrm{C}_{6} \mathrm{H}_{2}, 70 \%$ \\
\hline $\mathrm{H}_{3} \mathrm{C}$ & $\mathrm{R}^{1}=4-\mathrm{MeOC}_{6} \mathrm{H}_{4}, \mathrm{R}^{2}=4-\mathrm{CH}_{2}=\mathrm{CHCOOC}_{6} \mathrm{H}_{4}$ \\
\hline
\end{tabular}


<smiles>O=C(O)C1c2ccccc2Oc2ccccc21</smiles>

$$
+\mathrm{R}^{2} \mathrm{HC}=\mathrm{NR}^{1} \quad \underset{\mathrm{CH}_{2} \mathrm{Cl}_{2}}{\stackrel{36, \mathrm{Et}_{3} \mathrm{~N}}{\longrightarrow}}
$$

35

(for $\mathrm{R}^{1}$ and $\mathrm{R}^{2}$, see Table 1)

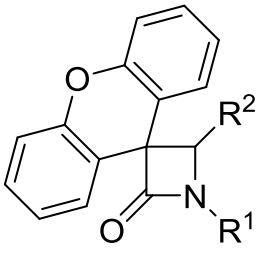

37

\section{Scheme 10}

The substituted norbornane carboxylic acids $\mathbf{3 8}$ have been used for the formation of the corresponding bicyclic norbornane-derived ketenes by a two-step procedure. The cycloaddition of the so-formed ketenes with imine 39 led to the generation of diastereomeric norbornane C3-spiro- $\beta$-lactams 40, 41, 42, 43 (Scheme 11, Table 2). It is noteworthy that the stereochemical outcome of spiro- $\beta$-lactams $\mathbf{4 0 - 4 3}$ is influenced by the presence of encumbering groups on the cyclic ketenes. In fact, a better selectivity was obtained when methyl groups were present near to the carbon bearing the carboxylic functional group. The ratio of diastereoisomers was determined by integration of the $\mathrm{H}-4$ proton in the ${ }^{1} \mathrm{H}-\mathrm{NMR}$ spectra of the crude reaction mixtures. ${ }^{45}$

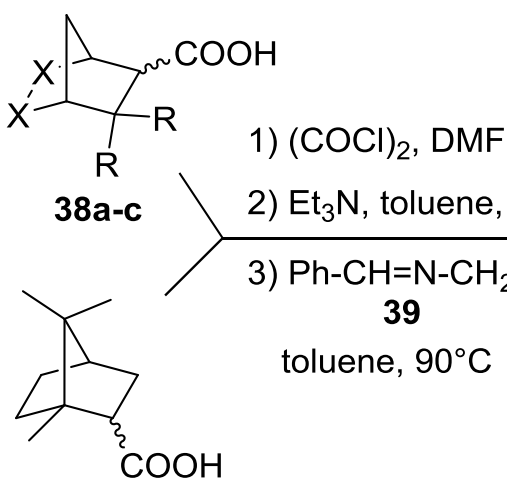

38d

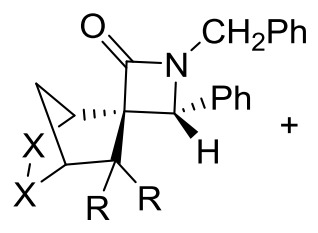

$40 \mathrm{a}-\mathrm{c}$

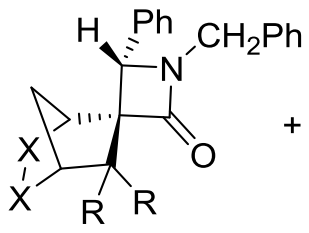

41a-c

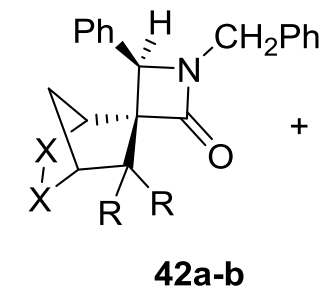

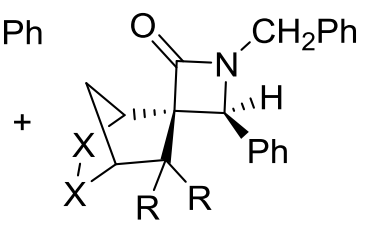

43a-b mixture diastereoisomers

$(12 \%)$

\section{Scheme 11}

Table 2. Total yields and ratios of spiro- $\beta$-lactams $40-43$ (a-c)

\begin{tabular}{ccccccccc}
\hline \multirow{2}{*}{$\begin{array}{c}\text { Carboxylic } \\
\text { acids }\end{array}$} & \multirow{2}{*}{$\mathrm{X}-\mathrm{X}$} & $\mathrm{R}$ & Total yield & \multicolumn{4}{c}{ Diastereomeric ratio (\%) } \\
\cline { 5 - 8 } & & & $(\%)$ & $\mathbf{4 0}$ & $\mathbf{4 1}$ & $\mathbf{4 2}$ & $\mathbf{4 3}$ \\
\hline 38a & $\mathrm{CH}=\mathrm{CH}$ & $\mathrm{H}$ & 98 & 46 & 27 & 20 & 7 \\
38b & $\mathrm{CH}_{2}-\mathrm{CH}_{2}$ & $\mathrm{H}$ & 94 & 53 & 29 & 9 & 9 \\
$38 \mathbf{3 8}$ & $\mathrm{CH}_{2}-\mathrm{CH}_{2}$ & $\mathrm{CH}_{3}$ & 68 & 47 & 53 & - & - \\
\hline
\end{tabular}

To study the synthesis of spiro- $\beta$-lactam $\mathbf{4 6}$ on a larger scale, the reaction of in situ generated ketene from compound $\mathbf{4 4}$ and imine $\mathbf{4 5}$ was conducted in both batch and flow mode (Scheme 12). The reaction outcome showed that the Staudinger synthesis in a continuous flow process was deemed a safe method for this highly 
exothermic reaction. However, the precipitation of generated salts quickly blocked a glass chip and made the operation technically impossible. ${ }^{46}$

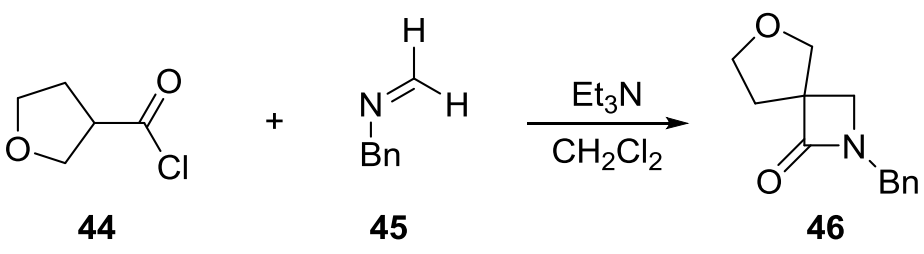

$(87 \%)$

\section{Scheme 12}

Recently, the Mykhailiuk group ${ }^{47,48}$ has reported on a new approach for the synthesis of 3-substituted piperidinyl spiro- $\beta$-lactam 51 starting from acid 47 and aldehyde $\mathbf{4 9}$ (Scheme 13). In this synthetic approach, acid $\mathbf{4 7}$ was firstly converted into the corresponding acid chloride and subsequently into ketene $\mathbf{4 8}$ by the sequential treatment with $\mathrm{SOCl}_{2}$ and $\mathrm{NEt}(i \mathrm{Pr})_{2}$. Aldehyde $\mathbf{4 9}$ was converted into imine $\mathbf{5 0}$ upon treatment with LiN(TMS $)_{2}$. In analogy, a diverse number of spiro- $\beta$-lactams attached with 4-, 5-, 6-, 7-membered rings at the C3 position were prepared in moderate to good yields. Subsequently, the reductive removal of the carbonyl group of spiro- $\beta$-lactam analogs $\mathbf{5 1}$ was conducted by the reducing reagent $\mathrm{AlH}_{3}$ giving the corresponding spirocyclic azetidines, which were investigated further in drug design and as an analog of the anesthetic drug bupivacaine. ${ }^{47,48}$<smiles>O=C(O)C1CCN(C(=O)c2ccccc2)CC1</smiles>

47<smiles>CC(C)C=O</smiles>

49

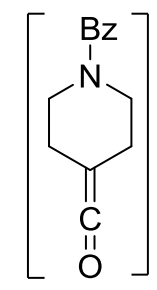

48

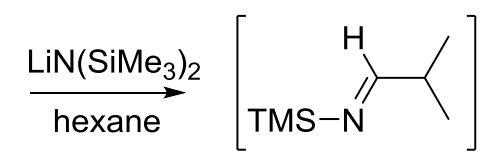

50

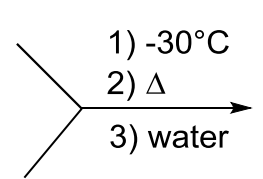

$\mathrm{Bz} 、$<smiles>CC(C)C1NC(=O)C12CCN(C)CC2</smiles>

51

(64\%)

\section{Scheme 13}

\subsection{Cyclization reactions}

A convenient entry toward the construction of spirocylic $\beta$-lactams comprises the cyclization of $\beta$-amino acid derivatives and $\beta$-functionalized amides. ${ }^{13}$ In that respect, Zhang and co-workers ${ }^{49}$ have developed novel synthetic routes to produce several spiro-4-cyclohexadienonyl- $\beta$-lactams 53 from $N$-(4-hydroxyphenyl)-3oxopropanamides 52 through dearomatization and cyclization processes with iodobenzene diacetate (IBD) as oxidant in the presence of a stoichiometric amount of copper(II) sulfate pentahydrate and 4-dimethylaminopyridine (DMAP). ${ }^{49}$ Later, this method was modified by using only a catalytic amount of copper(II) sulfate pentahydrate and 4-dimethylaminopyridine (DMAP), which gave similar yields (Scheme 14). ${ }^{50}$ 


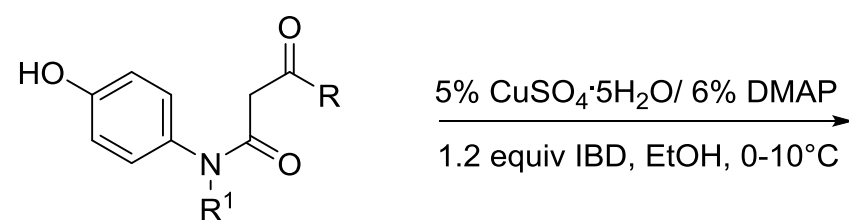

52

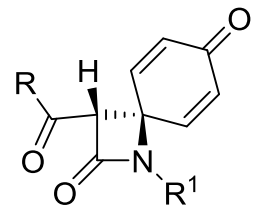

53

$(45-95 \%)$

$\mathrm{R}=\mathrm{CH}_{3}, \mathrm{Ph}, \mathrm{OEt}, \mathrm{CH}_{3} \mathrm{CH}_{2}, \mathrm{CH}_{3} \mathrm{CH}_{2} \mathrm{CH}_{2}, \mathrm{CH}_{3} \mathrm{CH}_{2} \mathrm{CH}_{2} \mathrm{CH}_{2} \mathrm{CH}_{2}, \mathrm{CH}_{3} \mathrm{CH}=\mathrm{CH}_{2}$<smiles>[R]#[PH]Oc1ccc(-c2ccccc2)cc1</smiles>

\section{Scheme 14}

In addition, this modification also allowed for the synthesis of a diverse number of spiro-4cyclohexadienone- $\beta$-lactams 55 with cyclopentanone, $\gamma$-lactone, and $\gamma$-lactam side chains on their $C 3$ position, starting from the corresponding amides 54 (Scheme 15). ${ }^{50}$

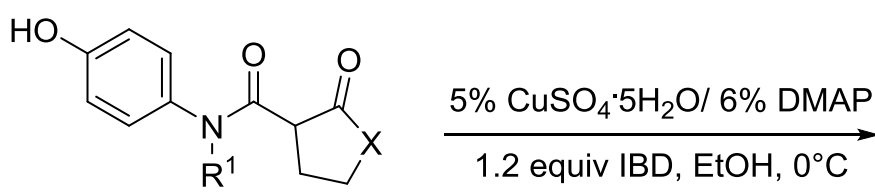

54

$\mathrm{R}^{1}=\left(\mathrm{CH}_{3}\right)_{2} \mathrm{CHCH}_{2}, \mathrm{Bn}, 4-\mathrm{MeOC}_{6} \mathrm{H}_{4}$

$\mathrm{X}=\mathrm{CH}_{2}, \mathrm{O}, \mathrm{NBn}, \mathrm{NBoc}$

\section{Scheme 15}

Furthermore, the replacement of copper(II) sulfate pentahydrate by $\left[\mathrm{Cu}_{3}((S)-\mathrm{PIA})_{2}(1,4-\right.$ dioxane) $\left(\mathrm{H}_{2} \mathrm{O}\right)_{2}$ 2 2(1,4-dioxane) $\mathrm{H}_{2} \mathrm{O}(\mathrm{L}-1)$ has been shown to be equally effective in the preparation of spiro-4cyclohexadienonyl- $\beta$-lactam analogs. ${ }^{51}$

In independent research, $\mathrm{Xu}$ has described the synthesis of 4-spiro-cyclohexadienonyl- $\beta$-lactam-3-carbonitriles $\mathbf{5 7}$ by means of the intramolecular nucleophilic cyclization of $N$-( $p$-hydroxyphenyl)cyanoacetamides $\mathbf{5 6}$ with iodobenzene diacetate (IBD) as oxidant and potassium hydroxide as base (Scheme 16). ${ }^{10}$<smiles>[R]N(C(=O)CC#N)c1ccc(O)cc1</smiles>

56

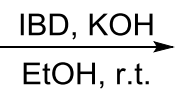

EtOH, r.t.

$(57-95 \%)$

$\mathrm{R}^{1}=\mathrm{Bn}, 4-\mathrm{MeOC}_{6} \mathrm{H}_{4} \mathrm{CH}_{2}, 3-\mathrm{MeOC}_{6} \mathrm{H}_{4} \mathrm{CH}_{2}, 2-\mathrm{MeOC}_{6} \mathrm{H}_{4} \mathrm{CH}_{2}$, 3,4-(MeO) $)_{2} \mathrm{C}_{6} \mathrm{H}_{3} \mathrm{CH}_{2}, 4-\mathrm{FC}_{6} \mathrm{H}_{4} \mathrm{CH}_{2}, 4-\mathrm{ClC}_{6} \mathrm{H}_{4} \mathrm{CH}_{2}, 3-\mathrm{ClC}_{6} \mathrm{H}_{4} \mathrm{CH}_{2}$, 2- $\mathrm{ClC}_{6} \mathrm{H}_{4} \mathrm{CH}_{2}, 4-\mathrm{BrC}_{6} \mathrm{H}_{4} \mathrm{CH}_{2}, 4-\mathrm{NCC}_{6} \mathrm{H}_{4} \mathrm{CH}_{2}, 4-\mathrm{NO}_{2} \mathrm{C}_{6} \mathrm{H}_{4} \mathrm{CH}_{2}$, $\left(\mathrm{CH}_{3}\right)_{2} \mathrm{CH}$,

\section{Scheme 16}<smiles>Cc1ccc2ccccc2c1</smiles><smiles>[CH2]c1ccco1</smiles> 
The cyclization of Dab-derived (Dab = 2,4-diaminobutanoic acid) chloroacetyl compound 59, which was obtained in a quantitative yield by treatment of compound $\mathbf{5 8}$ with chloroacetyl chloride in the presence of propylene oxide, gave rise to 1,6-diazaspiro[3.4] octane-2,5-dione 60 (Scheme 17). The construction of spirocylic $\beta$-lactam 60 could be explained by the concomitant formation of the $\beta$-lactam and pyrrolidinone ring, the latter due to a 5-exo-trig ring closure between the ZNH group and the carboxylic ester, followed by Zprotecting group removal. $^{52}$
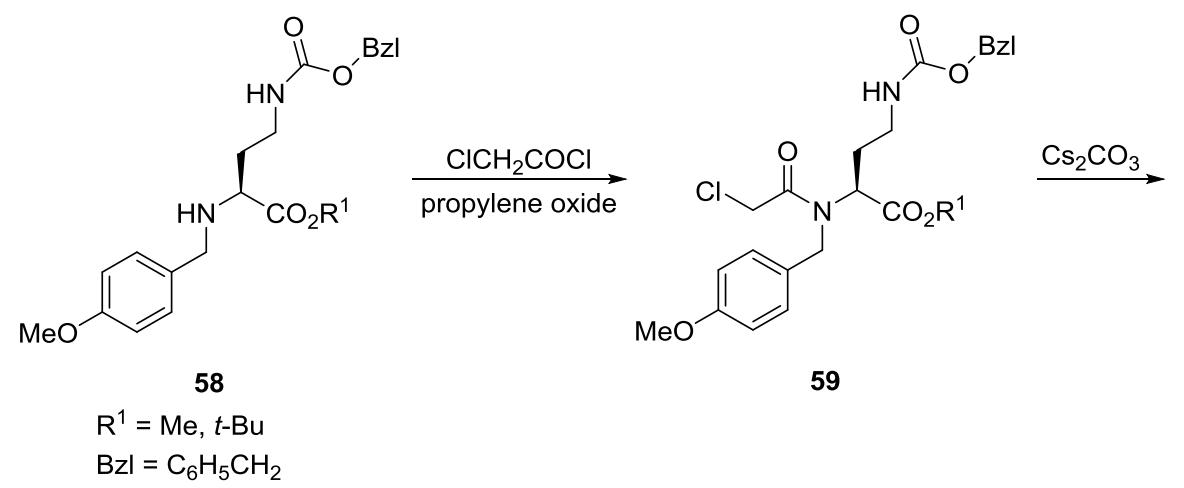

59

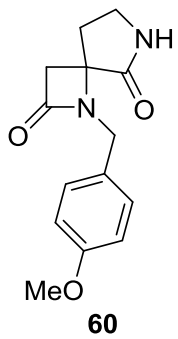

$(58 \%)$

\section{Scheme 17}

In the course of a study on proline-like compounds with potential biological interest, Ponticelli and coworkers $^{53}$ have devised an approach toward the synthesis of functionalized spiro-pyrrolidine 63 (Scheme 18). In particular, treatment of pyrrolidine aldehyde $\mathbf{6 1}$ with the reducing reagent $\mathrm{NaCNBH}_{3}$, together with methylamine, gave rise to the $\beta$-amino ester 62 . Subsequently, the cyclization of compound $\mathbf{6 2}$ using two equivalents of the strong base LDA led to the desired spiro- $\beta$-lactam $63 .^{53}$ In independent research, Sharada and coworkers have also described an effective synthesis of a pyrrolidine-derived spiro- $\beta$-lactam starting from natural proline. ${ }^{54}$

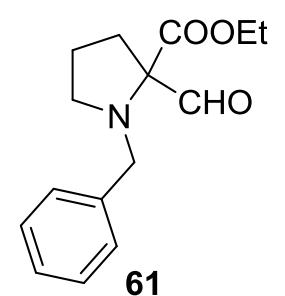

61
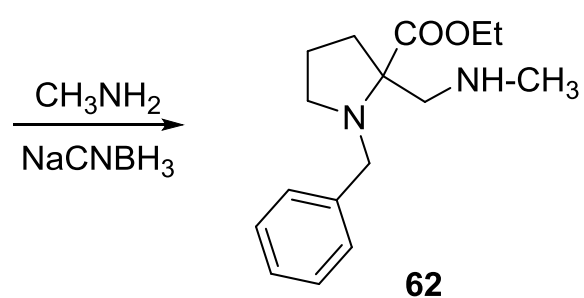

$(60 \%)$

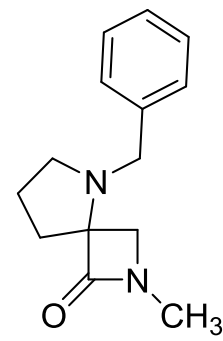

63 $(55 \%)$

\section{Scheme 18}

The Grainger group ${ }^{55}$ has published the preparation of a spirocyclic $\beta$-lactam by using a 4-exo-trig carbamoyl radical cyclization approach. Specifically, amine 64, prepared in one step by reductive amination of commercially available 1 -cyclohexene-1-carboxaldehyde with $p$-methoxyaniline, ${ }^{11}$ was converted into the carbamoyl radical precursor 65 (Scheme 19). Then, irradiation of compound 65 with a $500 \mathrm{~W}$ halogen lamp afforded spirocyclic dithiocarbamate 66 as a single diastereomer. The stereochemistry of compound 66 was 
determined by NOE spectral analysis, which showed the proton adjacent to sulfur to be on the same side of the cyclohexyl ring as the methylene group of the $\beta$-lactam. The reduction of 66 with $\mathrm{H}_{3} \mathrm{PO}_{2}-\mathrm{ACCN}$ successfully gave spirocyclic $\beta$-lactam 67 . $^{55}$

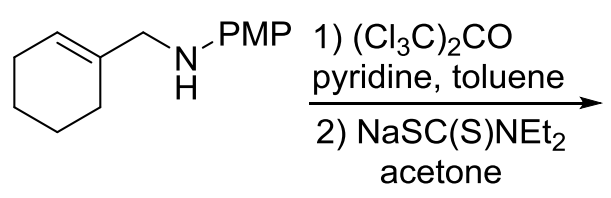

64<smiles>CCNC(=S)SC(=O)N(CC)CC1=CCCCC1</smiles>

65

$(65 \%)$

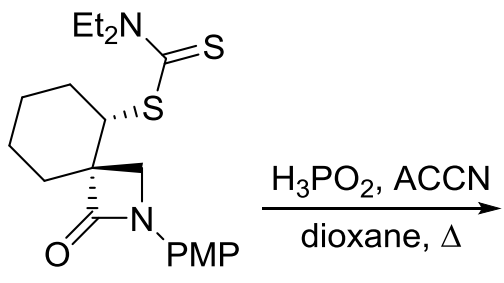

66

$(60 \%)$

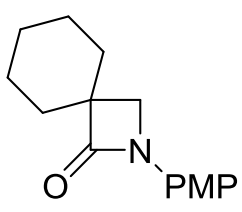

67

$(39 \%)$

\section{Scheme 19}

Spiro- $\beta$-lactam 75 has been synthesized as an intermediate compound in an effort to find drugs to improve hepatitis C virus (HCV) therapy (Scheme 20). ${ }^{56}$ 1,2-Bis(bromomethyl)benzene 68 was condensed with diethyl malonate 69, furnishing a crude diethyl malonate derivative. This derivative was reacted with sulfuric acid in the presence of methanol at $200{ }^{\circ} \mathrm{C}$, giving methyl ester $\mathbf{7 0}$. Treatment of ester 70 with LDA afforded the corresponding enolate, which was trapped with TMSCl leading to silyl enol ether 71. Reaction of generated enol 71 with $N$-p-methoxyphenyl (PMP) imine $\mathbf{7 2}$ in the presence of TMSOTf gave compound $\mathbf{7 3}$ as a mixture of enantiomers. Cyclization of compound $\mathbf{7 3}$ with $\mathrm{MeMgBr}$ gave rise to spiro compound $\mathbf{7 4}$ in $70 \%$ yield. Removal of the PMP group of spiro- $\beta$-lactam 74 with CAN led to the desired compound $75 .{ }^{56}$<smiles>CCOC(=O)CC(=O)OCC</smiles>

68

69
1) $\mathrm{Na}, \mathrm{KOH}, \mathrm{EtOH}$

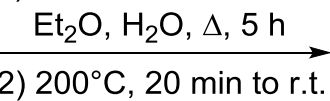
$\mathrm{H}_{2} \mathrm{SO}_{4}, \mathrm{MeOH}, \Delta, 1 \mathrm{~h}$

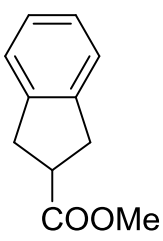

70

(26\%)

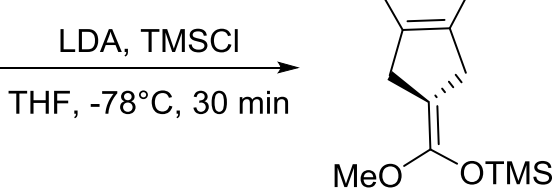

71 (56\%)

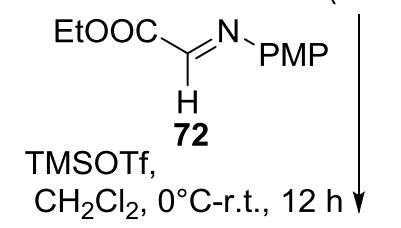<smiles>CCOC(=O)C1NC(=O)C12Cc1ccccc1C2</smiles>

75

(56\%)

5

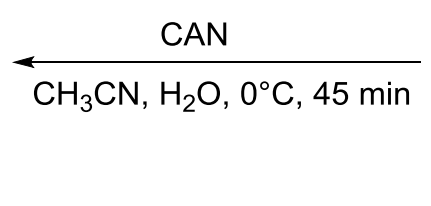

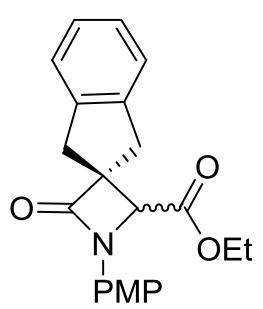

74

(70\%)

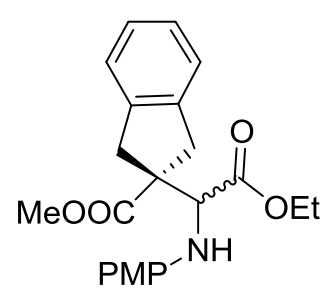

73 $(79 \%)$

\section{Scheme 20}


Indolenine $\beta$-lactams 77, present as key moieties in the complete structure of chartellines, were synthesized by an intramolecular nucleophilic substitution initiated by indolenine derivatives 76 using LiHMDS as a base (Scheme 21). ${ }^{57}$<smiles>[R]c1ccc2c(CC(=O)N(C)O[Na])c(C)[nH]c2c1</smiles>

76

$\mathrm{R}=\mathrm{H}, \mathrm{Br}$

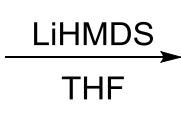

$\mathrm{R}^{\prime}$

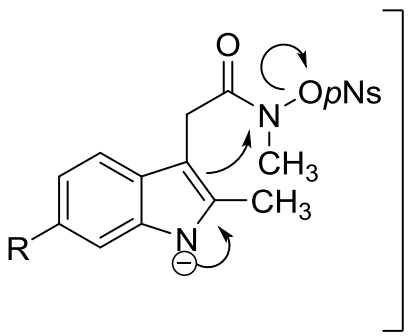<smiles>[R]c1ccc2c(c1)N=C(C)C21CC(=O)N1C</smiles>

77

$(50-62 \%)$

\section{Scheme 21}

A highly regioselective intramolecular amination of an $\mathrm{sp}^{3}$ carbon in amide derivatives bearing an 8aminoquinolinyl group as the bidentate directing group using transition metal catalysts has recently attracted considerable attention of different research groups. ${ }^{58-63}$ The intramolecular dehydrogenative cyclization of aliphatic amides $\mathbf{7 8}$ afforded spiro- $\beta$-lactams $\mathbf{7 9}$ by utilizing a bidentate chelation and various oxidants in combination with copper, nickel and cobalt catalysts (Scheme 22). The formation of $\beta$-lactams was proposed to proceed in all cases via $\mathrm{C}-\mathrm{N}$ bond-forming reductive elimination. ${ }^{63}$

1) $\mathrm{CuCl}(20 \mathrm{~mol} \%), 1.2$ equiv duroquinone 1.5 equiv $\mathrm{PhCO}_{2} \mathrm{Na}$, o-xylene, air, $160^{\circ} \mathrm{C}$

2) $\left[\mathrm{Cu}(\mathrm{OAc})_{2}\right](20 \mathrm{~mol} \%), 3.0$ equiv $\mathrm{Ag}_{2} \mathrm{CO}_{3}$ $\mathrm{Cl}\left(\mathrm{CH}_{2}\right)_{2} \mathrm{Cl}, 140^{\circ} \mathrm{C}, 24 \mathrm{~h}$<smiles>[R]CC1(C(=O)Nc2ccc([X])c3cccnc23)CCCC1</smiles>

78

$\mathrm{R}=\mathrm{H}, \mathrm{Ph}, \mathrm{CH}_{3}$

$\mathrm{X}=\mathrm{H}, \mathrm{Cl}$

$\mathrm{n}=0,1,2$
3) Cul (20 mol\%), $\mathrm{O}_{2}$ (1 atm), 2 equiv $\mathrm{Na}_{2} \mathrm{CO}_{3}$ $\mathrm{PhCN} / \mathrm{o}$-xylene $(3 / 2), 140^{\circ} \mathrm{C}, 34 \mathrm{~h}$

4) $\left[\mathrm{Ni}(\mathrm{dme})_{2} \mathrm{l}_{2}\right](10 \mathrm{~mol} \%), 3$ equiv TEMPO 2 equiv $\mathrm{K}_{2} \mathrm{HPO}_{4}, 0.1$ equiv TBAI, $n \mathrm{PrCN} / \mathrm{PhCN}, 150^{\circ} \mathrm{C}$

5) $\mathrm{Ni}(\mathrm{OTf})_{2}(10 \mathrm{~mol} \%), \mathrm{Ag}_{2} \mathrm{CO}_{3}(25 \%)$ 2 equiv $\mathrm{Na}_{2} \mathrm{CO}_{3}$, DMF, $140^{\circ} \mathrm{C}, 24 \mathrm{~h}$

6) $\mathrm{Co}(\mathrm{OAc})_{2}$ (10 mol\%), 2.5 equiv $\mathrm{Ag}_{2} \mathrm{CO}_{3}$ 0.5 equiv $\mathrm{PhCO}_{2} \mathrm{Na}, \mathrm{PhCl}, 150^{\circ} \mathrm{C}$

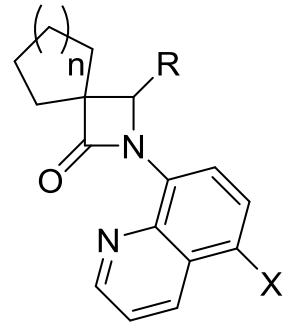

79

$(27-90 \%)$

\section{Scheme 22}

The direct $\mathrm{C}-\mathrm{H}$ cyclization of amides $\mathbf{8 0}$ bearing five-, six- and seven-membered rings proceeded via in situ iodonium ylide formation $\mathbf{8 0}$ " without the assistance of a transition metal, delivering the corresponding spiro$\beta$-lactams $\mathbf{8 1}$ in a single step (Scheme 23). From a mechanistic point of view, this transformation is consistent with the facile formation of a reactive singlet carbene. However, it circumvents the classical use of diazo substrates for $\mathrm{C}-\mathrm{H}$ insertion chemistry. ${ }^{64}$ 


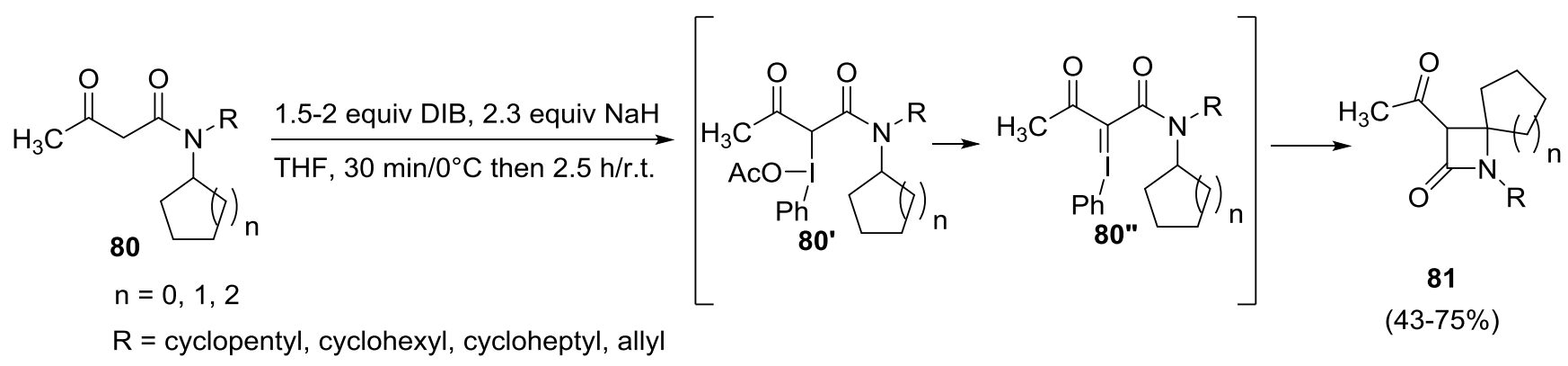

\section{Scheme 23}

Phototransformation chemistry has demonstrated a great potential for challenging building block synthesis. In that regard, the irradiation (direct excitation at $\sim 350 \mathrm{~nm}$ or triplet sensitization with thioxanthone at $\sim 420 \mathrm{~nm}$ ) of atropisomeric enones $\mathbf{8 2}$ gave rise to the corresponding spiro- $\beta$-lactam photoproducts 83 (as major products) and 84 (as minor products) (Scheme 24). Computational investigation revealed that the presence of an ortho-tert-butyl substituent on atropisomeric enones $\mathbf{8 2}$ prevented the $6 \pi$-photocyclization to undergo an efficient hydrogen abstraction leading to atropselective spiro- $\beta$-lactam formation. ${ }^{65,66}$<smiles>[R]c1ccc([R])c(N(CC)C(=O)C2=CC(=O)CC(C)(C)O2)c1</smiles>

82

$\mathrm{R}^{1}=t-\mathrm{Bu}, \mathrm{R}^{2}=\mathrm{H}, \mathrm{R}^{3}=\mathrm{Ph}$

$\mathrm{R}^{1}=t-\mathrm{Bu}, \mathrm{R}^{2}=t-\mathrm{Bu}, \mathrm{R}^{3}=\mathrm{Ph}$

$\mathrm{R}^{1}=t-\mathrm{Bu}, \mathrm{R}^{2}=\mathrm{H}, \mathrm{R}^{3}=\mathrm{H}$

$\mathrm{R}^{1}=t-\mathrm{Bu}, \mathrm{R}^{2}=\mathrm{H}, \mathrm{R}^{3}=p-\mathrm{BrC}_{6} \mathrm{H}_{4}$

$\mathrm{R}^{1}=t-\mathrm{Bu}, \mathrm{R}^{2}=\mathrm{H}, \mathrm{R}^{3}=p-\mathrm{CF}_{3} \mathrm{C}_{6} \mathrm{H}_{4}$

$\mathrm{R}^{1}=t-\mathrm{Bu}, \mathrm{R}^{2}=\mathrm{H}, \mathrm{R}^{3}=p-\mathrm{CH}_{3} \mathrm{C}_{6} \mathrm{H}_{4}$

$\mathrm{R}^{1}=t-\mathrm{Bu}, \mathrm{R}^{2}=\mathrm{H}, \mathrm{R}^{3}=p-\mathrm{OCH}_{3} \mathrm{C}_{6} \mathrm{H}_{4}$

$\mathrm{R}^{1}=t-\mathrm{Bu}, \mathrm{R}^{2}=\mathrm{H}, \mathrm{R}^{3}=$ pyridyl

$\mathrm{R}^{1}=t-\mathrm{Bu}, \mathrm{R}^{2}=\mathrm{H}, \mathrm{R}^{3}=$ furyl<smiles>[R]c1ccc([R])c(N2C(=O)[C@]3(CC(=O)CC(C)(C)O3)C2[R])c1</smiles>

83

ee $>95 \%$, d.e. $>90 \%$

$(15-52 \%)$

\section{Scheme 24}

Cyclization of propiolamide $\mathbf{8 5}$ with triphenylphosphine as a catalyst in ethanol under reflux furnished the corresponding spiro-3-methyleneazetidin-2-one $\mathbf{8 6}$ in a moderate yield (Scheme 25). The rather low yield of spiro- $\beta$-lactam 86 might be rationalized by the steric hindrance experienced in the 4-exo cyclization step. ${ }^{67}$ 
<smiles>C#CC(=O)N(CBr)C1CCCCC1=O</smiles>

85

$$
\underset{\mathrm{EtOH}, \Delta, 20 \mathrm{~h}}{\stackrel{\mathrm{PPh}_{3}(10 \mathrm{~mol} \%)}{\longrightarrow}}
$$

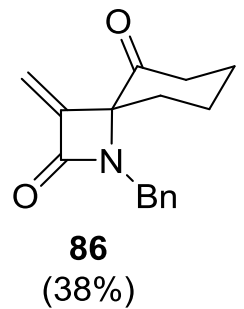

\section{Scheme 25}

Several methods based on $\mathrm{C}\left(\mathrm{sp}^{3}\right)-\mathrm{H}$ activation using $\mathrm{Pd}$ as a catalyst have recently been introduced to access a wide variety of ring systems. ${ }^{68-70}$ Boudoin and co-workers have described the utilization of carbamoyl chlorides $\mathbf{8 7}$ as appropriate substrates to construct spirocyclic $\beta$-lactams 88 through Pd-catalyzed $\mathrm{C}\left(\mathrm{sp}^{3}\right)-\mathrm{H}$ activation under both $\mathrm{CO}$ balloon and COgen (solid CO-releasing molecules) conditions (Scheme 26). ${ }^{71}$

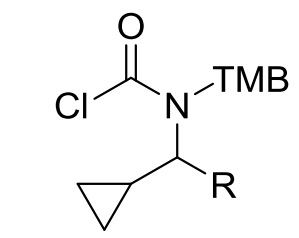

87
$\mathrm{PdCl}_{2}(10 \mathrm{~mol} \%)$

$\mathrm{PAd}_{2}(n-\mathrm{Bu}) \cdot \mathrm{HI}(20 \mathrm{~mol} \%)$

$\mathrm{PivOH}(30 \mathrm{~mol} \%), \mathrm{Cs}_{2} \mathrm{CO}_{3}$ (3 equiv)

mesitylene, $120^{\circ} \mathrm{C}, 18 \mathrm{~h}$

cond. A: COgen (3 equiv)

cond. B: CO (balloon)

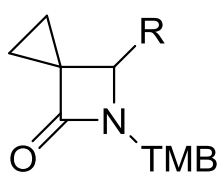

88

$(75-81 \%)$

$$
\mathrm{R}=\mathrm{H} \text {, cyclopropyl }
$$

\section{Scheme 26}

\subsection{Transformations of substituents connected to monocyclic azetidin-2-ones}

One of the most convenient methodologies for the preparation of spiro-fused $\beta$-lactams concerns the deployment of substituents on monocyclic azetidin-2-ones. In that respect, the Benito group has recently reported on the synthesis of spirocyclic seleno- $\beta$-lactams $\mathbf{9 0}$ from azetidin-2-one-tethered allenols $\mathbf{8 9}$ and the selenenylating reagent $N$-phenylselenophthalimide (NPSP) via ring enlargement (Scheme 27). ${ }^{72}$

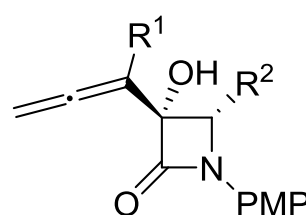

89

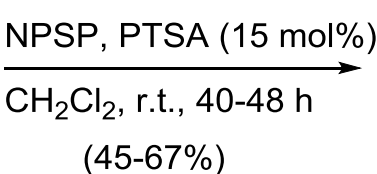

$(45-67 \%)$

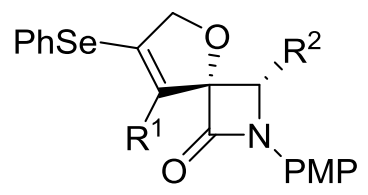

90

$$
\begin{aligned}
& \mathrm{R}^{1}=\mathrm{Ph}, \mathrm{R}^{2}=(S)-2,2-\text { dimethyl-1,3-dioxolan-4-yl } \\
& \mathrm{R}^{1}=\mathrm{Me}, \mathrm{R}^{2}=(S)-2,2-\text { dimethyl-1,3-dioxolan-4-yl } \\
& \mathrm{R}^{1}=\mathrm{Me}, \mathrm{R}^{2}=4-\mathrm{MeC}_{6} \mathrm{H}_{4} \\
& \mathrm{R}^{1}=\mathrm{Me}, \mathrm{R}^{2}=(R)-3-\text { methoxy-1-(4-methoxyphenyl)-2-oxoazetidinyl }
\end{aligned}
$$

\section{Scheme 27}


In addition, this group has disclosed a diastereoselective synthesis of spirocyclic $\beta$-lactam derivative (-)-92 starting from optically pure azetidine-2,3-dione (+)-91 applying Passerini reaction conditions with bromoacetic acid and benzyl isocyanide, followed by the addition of the non-nucleophilic base $N, N$ '-diisopropylethylamine (DIPEA) (Scheme 28). ${ }^{73}$<smiles>CC1(C)OC[C@H](C2C(=O)C(=O)N2P)[C@H]1P</smiles>

91 i) $\mathrm{BrCH}_{2} \mathrm{CO}_{2} \mathrm{H}, \mathrm{BnNC}$ $\mathrm{CH}_{2} \mathrm{Cl}_{2}$, r.t., $1.5 \mathrm{~h}$

ii) DIPE, $\mathrm{CH}_{2} \mathrm{Cl}_{2}$, r.t., $2 \mathrm{~h}$

$(56 \%)$

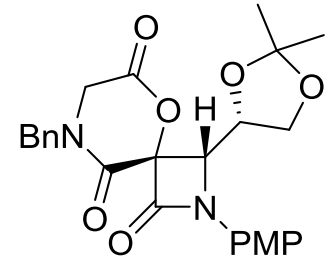

92

\section{Scheme 28}

6-Diazopenicillanates 94 have been obtained in high yields by the combination of 6 - $\beta$-aminopenicillanates 93 with ethyl nitrite at room temperature. Then, these 6-diazopenicillanates 94 were subjected to stereoselective 1,3-dipolar cycloaddition with acrylonitrile, acrylates and methyl vinyl ketone, giving the corresponding spiro-2-pyrazoline- $\beta$-lactam derivatives 95, 96 and 97 as major products (Scheme 29). It should be noted that the 1,3-dipolar cycloaddition was stereoselective, the major cycloadduct being the result of the dipolarophile addition to the less sterically hindered $\alpha$-side of the $\beta$-lactam. ${ }^{74}$
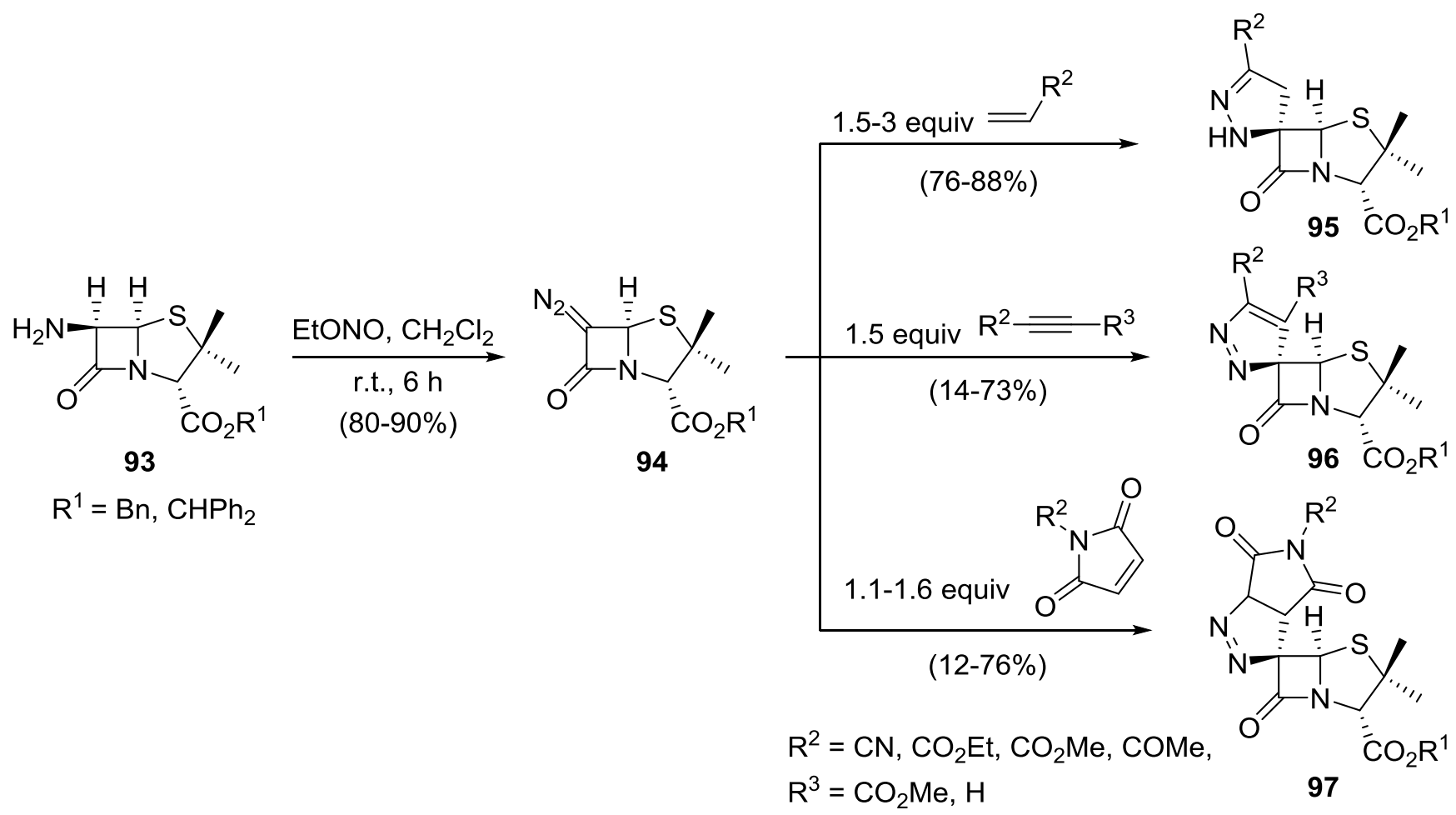

\section{Scheme 29}

In analogy, chiral spiropyrazolinepenicillanates 101, 102 and 103 were obtained in a stereoselective fashion via 1,3-dipolar cycloaddition of 6-alkylidenepenicillanates 100, prepared through Wittig reaction of the 
appropriate benzhydryl 6-oxopenicillanate 98 and phosphorus ylides 99, with the corresponding diphenyldiazomethane, diazomethane and phenyldiazomethane (Scheme 30). ${ }^{75}$

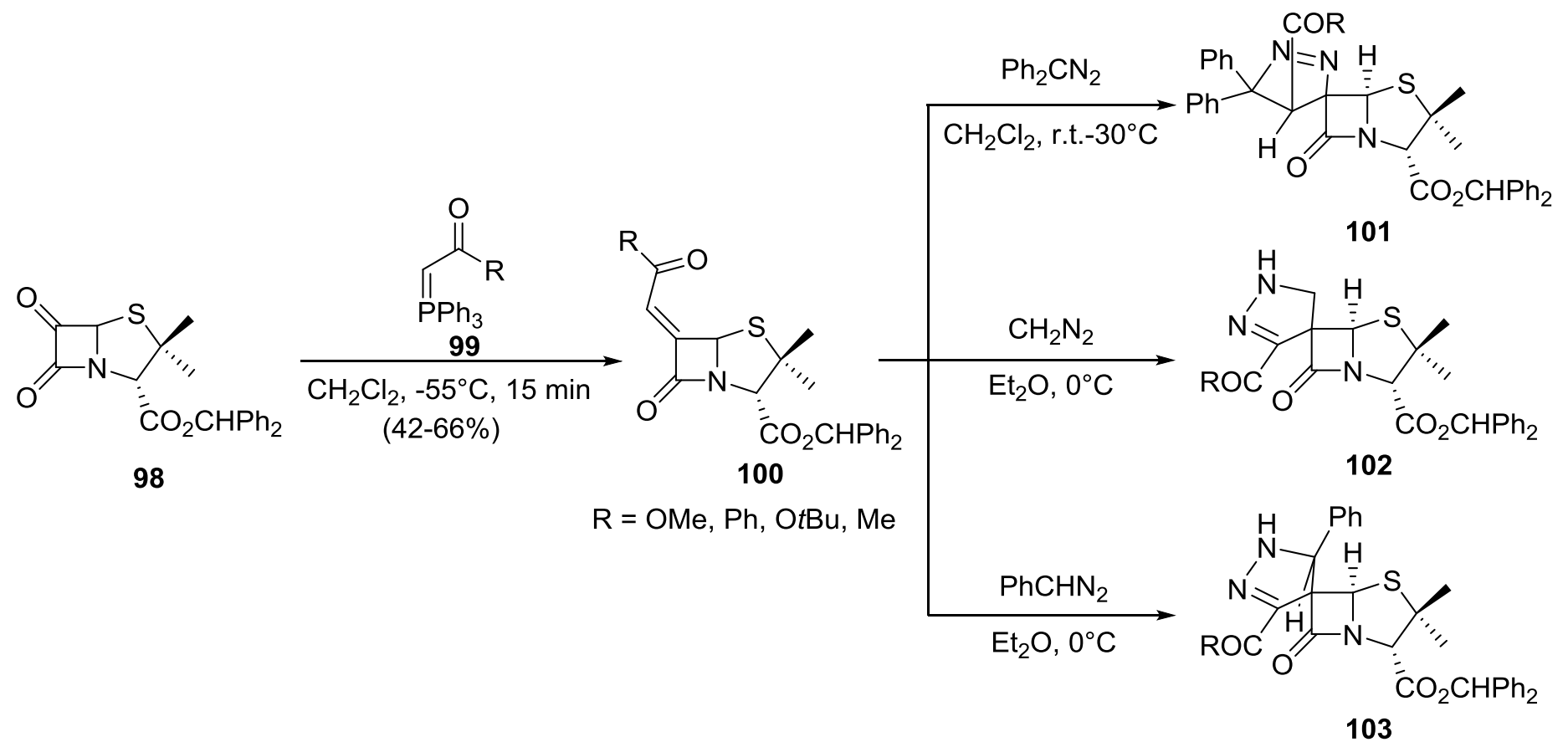

\section{Scheme 30}

In another study, the use of 10 mol\% copper(II) acetate monohydrate as a catalyst and air as the stoichiometric re-oxidant enabled the synthesis of spirocyclic oxindole $\beta$-lactam 105 via the cyclization of precursor 104 using mesitylene as the solvent (Scheme 31). ${ }^{12,76-78}$

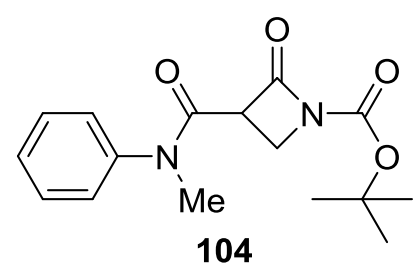

$\mathrm{Cu}(\mathrm{OAc})_{2} \cdot \mathrm{H}_{2} \mathrm{O}(10 \mathrm{~mol} \%)$ $\stackrel{\text { mesitylene, } 170^{\circ} \mathrm{C}, 30-90 \mathrm{~min}}{\longrightarrow}$

a) air atmosphere

b) air bubbled through

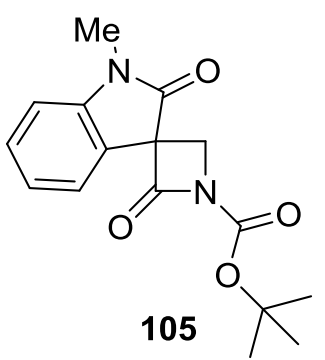

\section{Scheme 31}

Halocyclization of seleno- or thio-substituted $\beta$-lactams containing a carbon-carbon multiple bond concerns one of the pioneering methods for synthesis of halogenated 4-pyrazolyl spirocyclic- $\beta$-lactams. ${ }^{79-81}$ Bhalla has recently reported on the synthesis of halogenated 4-pyrazolyl spirocyclic- $\beta$-lactams 107-110 via halogen-mediated intrasulfenyl cyclization of cis-3-propynyloxy-4-pyrazolyl- $\beta$-lactams 106 (Scheme 32). The effect of halogenating reagents and selectivity on the formation of the product has been carefully considered. These novel spiro- $\beta$-lactams 107-110 have been submitted for molecular docking studies and in vitro evaluation for biological activity. ${ }^{80}$ 


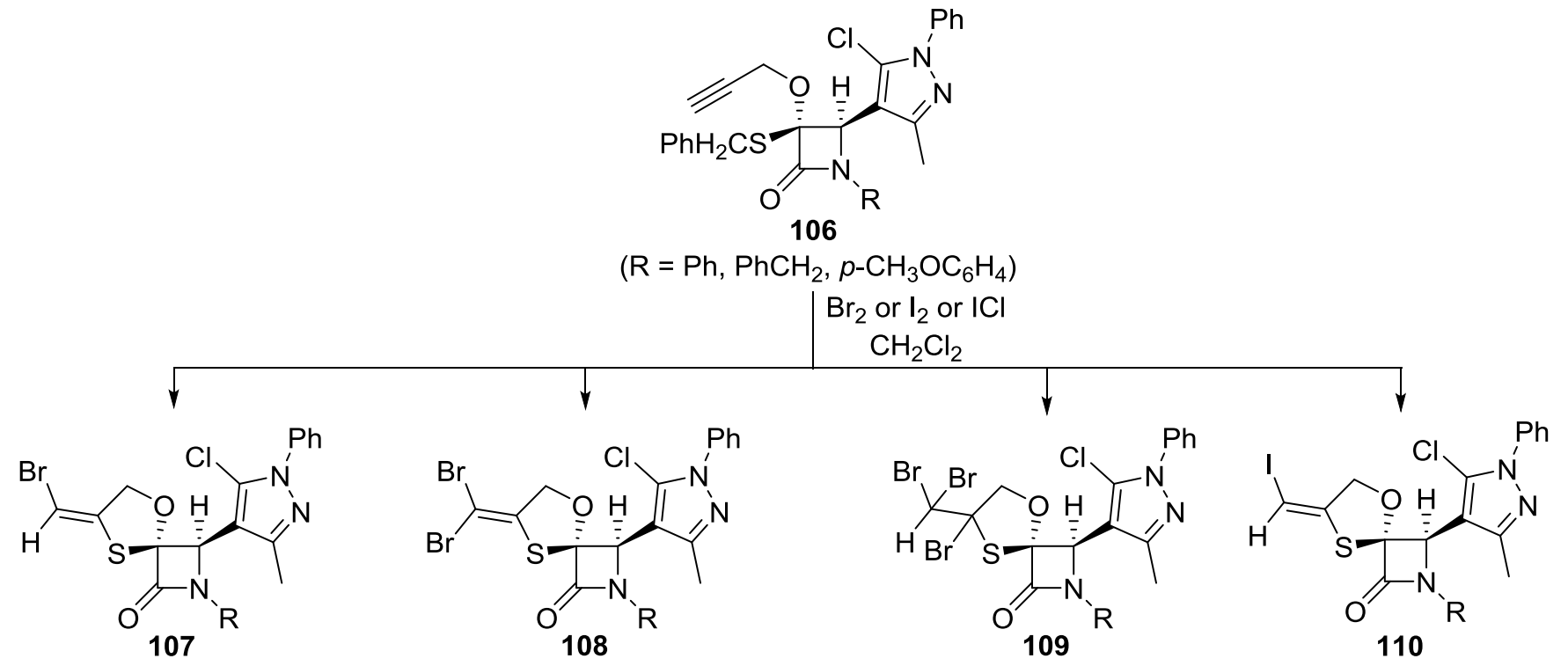

\section{Scheme 32}

The optically active $\alpha$-methylene- $\beta$-lactam (S)-111 has been subjected to cyclopropanation with $\mathrm{CH}_{2} \mathrm{~N}_{2}$ in $\mathrm{CH}_{2} \mathrm{Cl}_{2}$ and [3+2]-cycloaddition with diphenylnitrone, giving rise to the corresponding cyclopropane derivative $(S)-112$ in $85 \%$ yield and spiroisoxazolidine adduct (3S, 4S, 7S)-113 in 92\% yield, respectively (Scheme 33). ${ }^{82}$<smiles>C=C1C(=O)N(c2ccccc2)[C@H]1c1ccccc1</smiles>

$(S)-111$ ee $=96 \%$

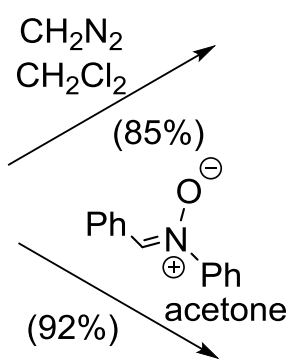<smiles>O=C1N(c2ccccc2)C(c2ccccc2)C12CC2</smiles>

$(S)-112$

ee $=96 \%$<smiles>O=C1O[C@]2(C[C@H](c3ccccc3)N(c3ccccc3)O2)[C@H]1c1ccccc1</smiles>

$(3 S, 4 S, 7 S)-113$

d.r. $=93: 7$ ee $=93 \%$

\section{Scheme 33}

Recently, the deployment of 3-methylene-4-(trifluoromethyl)azetidin-2-ones $\mathbf{1 1 2}$ as versatile building blocks allowed access to novel spiro-fused $\beta$-lactam systems. In particular, 1,3-dipolar nitrone-olefin cycloaddition of 3-methylene- $\beta$-lactams 112 with either $N$-phenyl- or $N$-tert-butyl- $\alpha$-phenylnitrone gave 3trifluoromethyl-5-oxa-2,6-diazaspiro[3.4]octan-1-ones 113 (Scheme 34). In addition, $\mathrm{CF}_{3}$-substituted spirocycles 115 and 116 were prepared upon treatment of the corresponding diols 114, derived from the $\mathrm{OsO}_{4}$-mediated oxidation of 3-methylene- $\beta$-lactams 112, with $\mathrm{pTsOH}$ in 2,2-dimethoxypropane and with triphosgene, respectively (Scheme 34). ${ }^{83,84}$ 


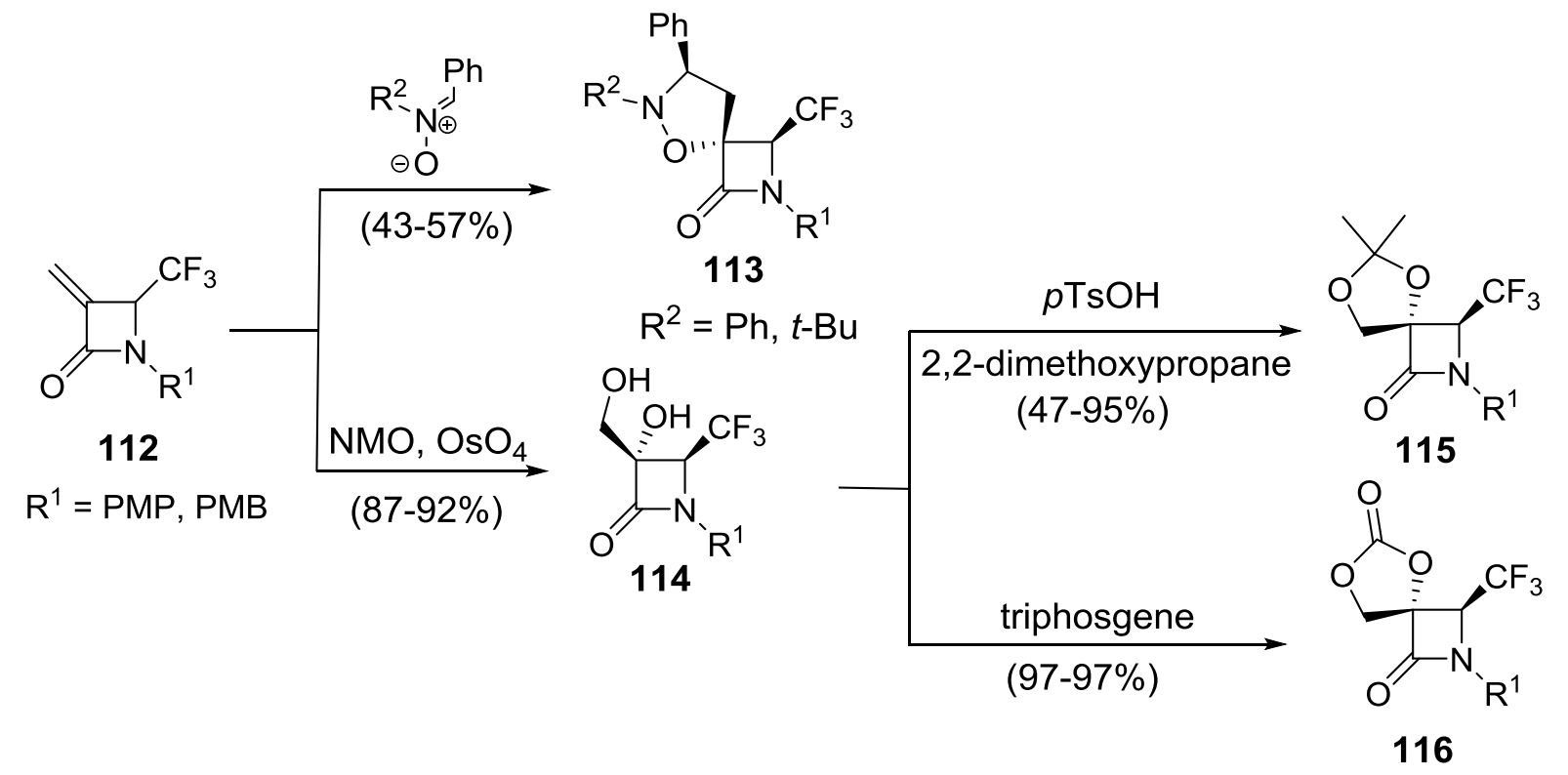

\section{Scheme 34}

Recently, $\mathrm{Li}$ and co-workers ${ }^{85}$ have developed a facile access to a broad range of trifluoromethylcontaining spirocyclic $\beta$-lactams via cycloaddition of $\alpha$-methylene- $\beta$-lactams 117 with $\mathrm{CF}_{3} \mathrm{CHN}_{2} 118$, which was generated in situ from 2,2,2-trifluoroethylamine hydrochloride and $\mathrm{NaNO}_{2}$ (Scheme 35). Under metal-free conditions, [3+2]-cycloaddition of $\alpha$-methylene- $\beta$-lactams 117 with $\mathrm{CF}_{3} \mathrm{CHN}_{2}$ led to 2-pyrazoline-containing spirocyclic $\beta$-lactams 119 as single diastereomers in good to high yields (82-96\%). On the other hand, the use of an iron catalyst (FeTPPCl) gave rise to cyclopropane-containing spirocyclic $\beta$-lactams 120 with good diastereoselectivity. The resulting spirocyclic $\beta$-lactams bearing a $\mathrm{CF}_{3}$ moiety are considered to be useful scaffolds for drug discovery and their further exploration in terms of biological activities. ${ }^{85}$

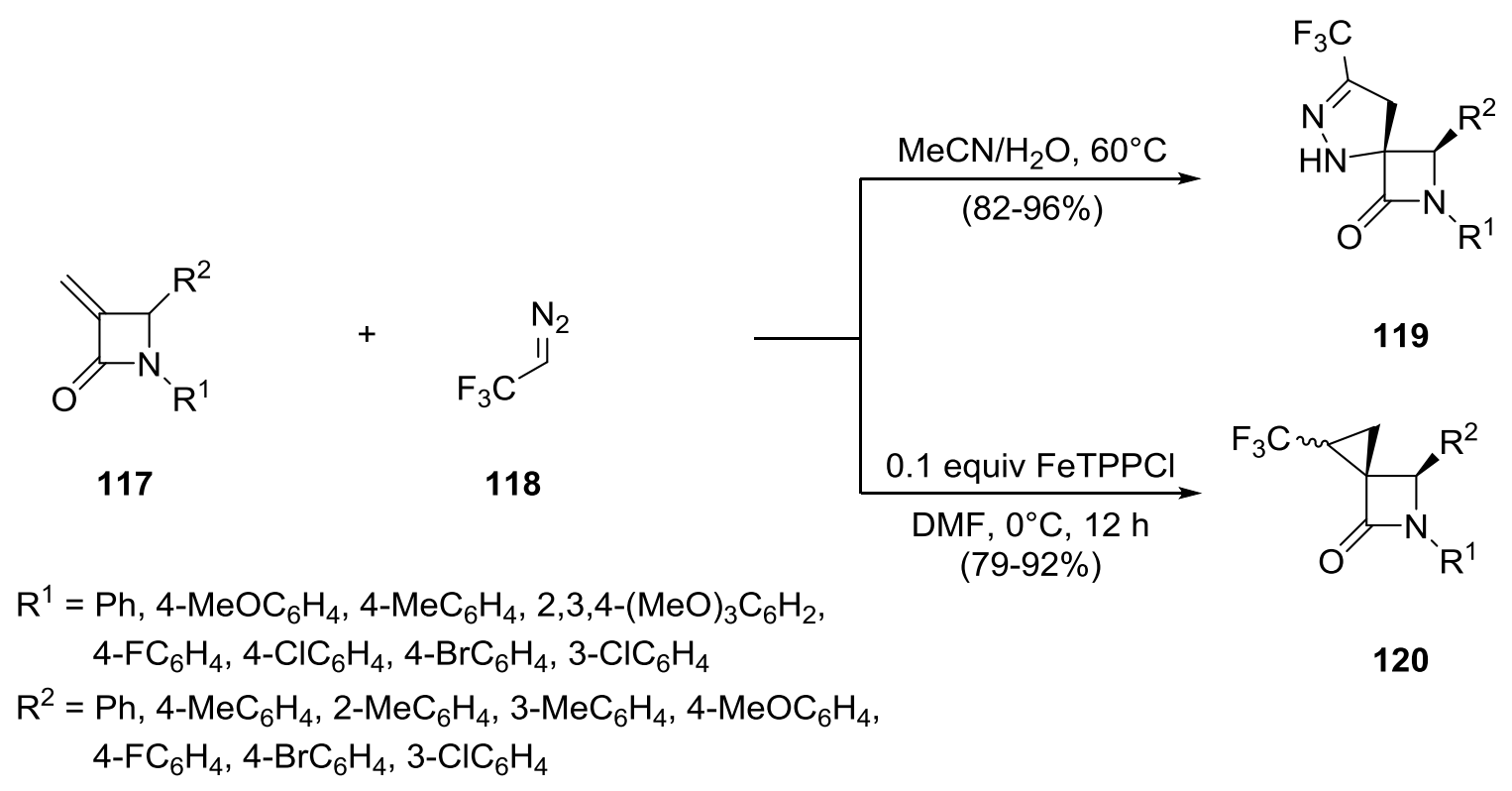

\section{Scheme 35}




\subsection{Other methods}

The reductive Mannich-type reaction of $\alpha, \beta$-unsaturated ester $\mathbf{1 2 1}$ with imine $\mathbf{1 2 2}$ using a Rh catalyst and $\mathrm{Et}_{2} \mathrm{Zn}$ provided a rapid access to spiro- $\beta$-lactam 123 (Scheme 36). A mechanism was proposed involving the formation of the rhodium-hydride complex $(\mathrm{Rh}-\mathrm{H})$ due to combination of $\mathrm{Et}_{2} \mathrm{Zn}$ and $\mathrm{RhCl}\left(\mathrm{PPh}_{3}\right)_{3}$. Subsequently, this complex catalyzed the 1,4-reduction of $\alpha, \beta$-unsaturated esters, resulting in a rhodium enolate as a Reformatsky-type reagent. In the end, this enolate reacted with imine 122, giving rise to spiro- $\beta$ lactam $123 .{ }^{86}$ In addition, the Willcox group has described the synthesis of an analog of spiro- $\beta$-lactam 123 by an aliphatic amine $\mathrm{C}-\mathrm{H}$ carbonylation process catalyzed by $\mathrm{Pd}{ }^{87}$

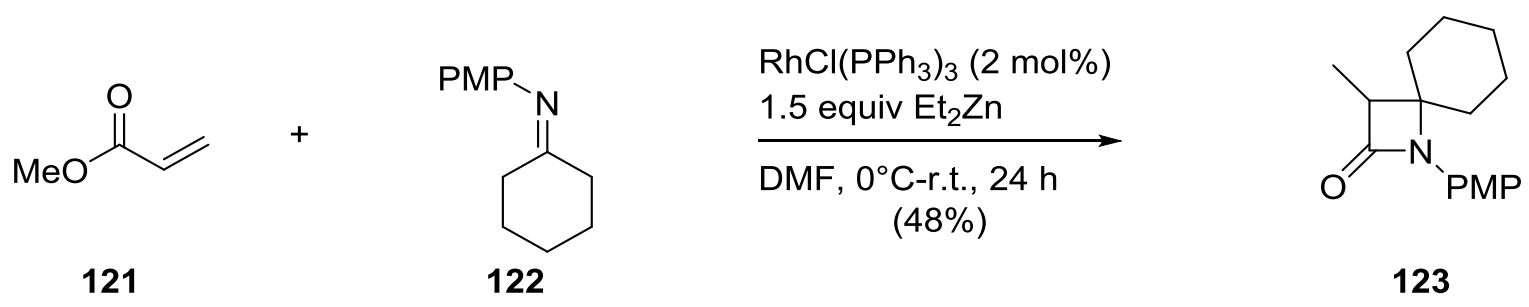

\section{Scheme 36}

The Bruce group has recently published the synthesis of spirocyclic $\beta$-lactams $\mathbf{1 2 6}$ through a palladiumcatalyzed multicomponent method, including participation of imines 125, ortho-iodo-substituted aryl imines 124 and CO (Scheme 37). The structure of the resulting spirocyclic $\beta$-lactams, bearing a trans orientation of the aromatic units, was confirmed by NOE and X-ray analysis. ${ }^{88}$<smiles>[R]N=Cc1ccccc1I</smiles>

124

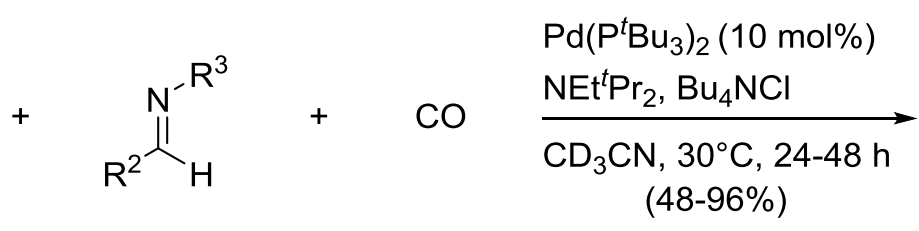

125

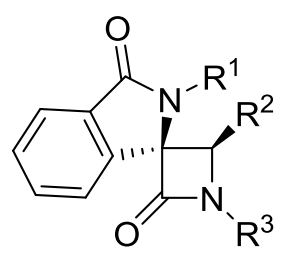

126

$\mathrm{R}^{1}=\mathrm{Bn}, \mathrm{Pr}, \mathrm{C}_{6} \mathrm{H}_{13}$

$\mathrm{R}^{2}=3$-pyridinyl, 4- $\mathrm{MeOC}_{6} \mathrm{H}_{4}, 4-\mathrm{CF}_{3} \mathrm{C}_{6} \mathrm{H}_{4}, 4-\mathrm{FC}_{6} \mathrm{H}_{4}, \mathrm{PhCH}=\mathrm{CH}$

$\mathrm{R}^{3}=\mathrm{Et}, \mathrm{Bn}$

\section{Scheme 37}

Recently, Enders and co-workers have investigated a novel approach utilizing a copper-catalyzed Kinugasa/Michael domino reaction of alkyne-tethered cyclohexadienones 127 and nitrones 128, providing unprecedented spirocyclic $\beta$-lactams 129 in good yields with excellent stereoselectivities (Scheme 38). ${ }^{89}$ 
<smiles>[R]C1([Y])C=CC(=O)C=C1</smiles>

127

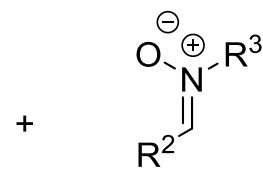

128

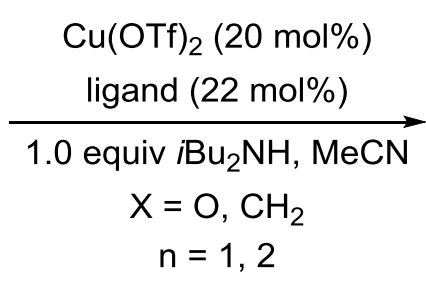

$\mathrm{n}=1,2$

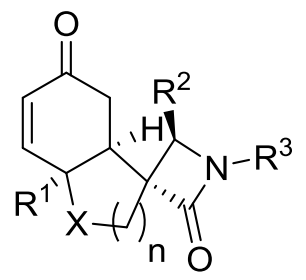

129

$\mathrm{R}^{1}=\mathrm{CH}_{3}, \mathrm{CH}_{3} \mathrm{CH}_{2}, \mathrm{Ph}, n \mathrm{Pr}, n \mathrm{Bu}, n$ Pent, $n \mathrm{Hex}, \mathrm{OMe}, 4-\mathrm{BrC}_{6} \mathrm{H}_{4}$

$\mathrm{R}^{2}=\mathrm{Ph}, 4-\mathrm{MeOC}_{6} \mathrm{H}_{4}, 4-\mathrm{ClC}_{6} \mathrm{H}_{4}, 3-\mathrm{BrC}_{6} \mathrm{H}_{4}, 4-\mathrm{MeC}_{6} \mathrm{H}_{4}$, 2-furyl

$e e=82-97 \%$, d.r. $>20: 1$

$(55-94 \%)$

\section{Scheme 38}

\section{Reactivity of Spiro-fused $\beta$-lactams}

Along with efforts to improve synthetic methodologies, the deployment of spiro-fused $\beta$-lactams as interesting synthons to construct complex heterocycles has also been explored. The reactivity of spiro-fused $\beta$-lactams is related to the nature of these four-membered cyclic amides and the presence of substituents on the ring. In this section, the behavior of spiro-fused $\beta$-lactams toward ring-opening and ring-transformation reactions will be considered.

\subsection{Ring-opening reactions}

In general, spiro-fused azetidin-2-ones often suffer from ring-opening reactions upon treatment with various acids, bases, reducing reagents and oxidative reagents. ${ }^{13}$ However, the treatment of 1-substituted spiro-fused $\beta$-lactams 130 with the reducing reagent $\mathrm{LiAlH}_{4}$ resulted in the unanticipated 3-benzhydryl-1-methylindole 131 as the major product, accompanied by a small amount of the ring-opening product 3-(2-hydroxy-1,1diphenylethyl)-3-(4-methoxyphenylamino)-1-methylindolin-2-ol 132 (Scheme 39). Furthermore, the cleavage of N1-C4 and C3-C4 bonds of azetidin-2-ones $\mathbf{1 3 0}$ has been investigated upon treatment with the oxidising reagent $C A N{ }^{90}$

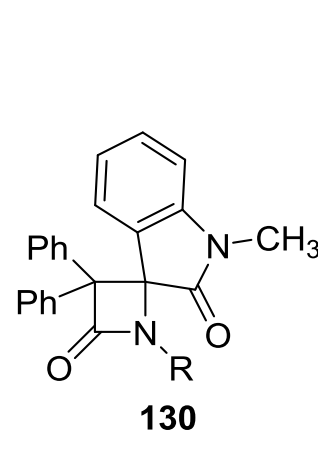

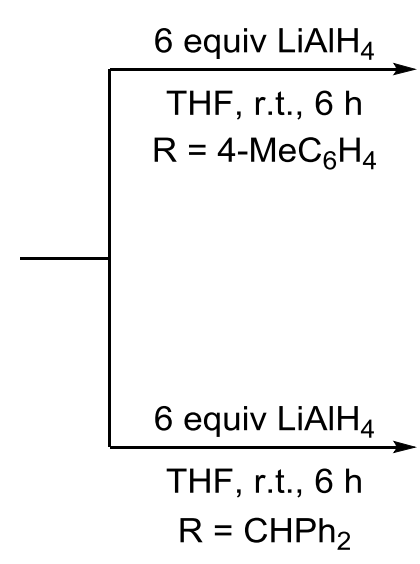<smiles>Cn1cc(C(c2ccccc2)c2ccccc2)c2ccccc21</smiles>

$(56 \%)$<smiles>Cn1cc(C(c2ccccc2)c2ccccc2)c2ccccc21</smiles>

131

$(61 \%)$ 
The employment of a Lewis-Brønsted acid in combination with a superacid catalyst system promoted a regiospecific N1-C2 ring-opening reaction of $\mathrm{N}$-aryl-3-spirocyclic- $\beta$-lactams 133 followed by a recyclization, providing an efficient entry to 3-spirocyclic quinolin-4(1H)-ones 134 in good to high yields (Scheme 40). ${ }^{91}$
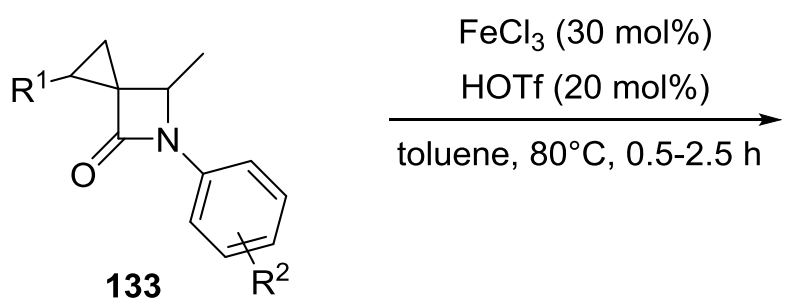<smiles>[R]c1ccc2c(c1)NC(C)C1(CC1[R])C2=O</smiles>

$$
\begin{aligned}
& \mathrm{R}^{1}=\mathrm{H}, \mathrm{R}^{2}=2-\mathrm{MeO}, 91 \% \\
& \mathrm{R}^{1}=\mathrm{H}, \mathrm{R}^{2}=4-\mathrm{MeO}, 88 \% \\
& \mathrm{R}^{1}=\mathrm{H}, \mathrm{R}^{2}=\mathrm{H}, 92 \% \\
& \mathrm{R}^{1}=\mathrm{H}, \mathrm{R}^{2}=2-\mathrm{Me}, 89 \% \\
& \mathrm{R}^{1}=\mathrm{H}, \mathrm{R}^{2}=4-\mathrm{Me}, 90 \% \\
& \mathrm{R}^{1}=\mathrm{H}, \mathrm{R}^{2}=2,4-\mathrm{diMe}, 81 \% \\
& \mathrm{R}^{1}=\mathrm{H}, \mathrm{R}^{2}=2-\mathrm{Cl}, 87 \% \\
& \mathrm{R}^{1}=\mathrm{H}, \mathrm{R}^{2}=1 \text {-naphthyl, } 90 \%
\end{aligned}
$$

\section{Scheme 40}

The norbornane-derived spiro- $\beta$-lactams $\mathbf{4 0 - 4 1 b}$ have been subjected to acid hydrolysis ( $\mathrm{HBr}$ ), giving rise to the corresponding norbornane-derived $\beta$-amino acids 135 and 136 (Scheme 41). ${ }^{45}$

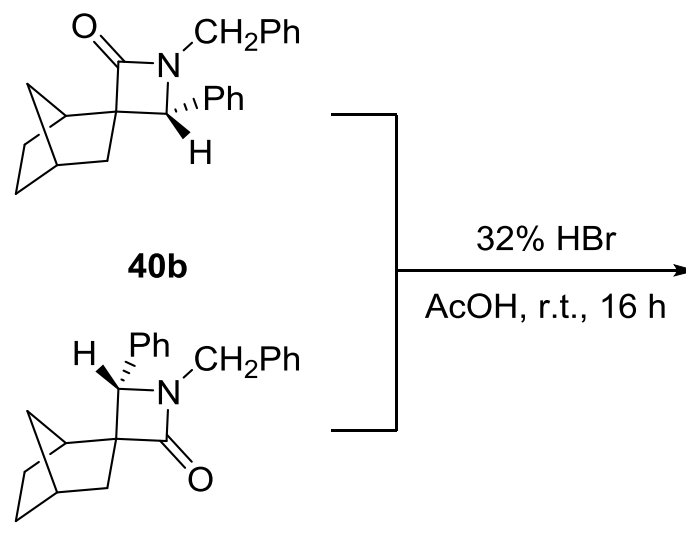

$41 b$<smiles>O=C(O)C1(C(NCc2ccccc2)c2ccccc2)CC2CCC1C2</smiles>

135

$(73 \%)$<smiles>O=C(O)C1(C(NCc2ccccc2)c2ccccc2)CC2CCC1C2</smiles>

136

$(71 \%)$

\section{Scheme 41}

The activation of spiro- $\beta$-lactam 141 with di-tert-butyl dicarbonate and subsequent intermolecular nucleophilic ring opening upon treatment with $\mathrm{DBU} / \mathrm{MeOH}$ afforded 2-oxopiperidino- $\beta$-amino ester 142 in excellent yield (Scheme 42). The preparation of spiro- $\beta$-lactam 141 was performed starting from $\beta$-lactam 138, which was synthesized from ornithine derivative 137 via a three-step procedure. Accordingly, the removal of the $Z$ protecting group from 138 by catalytic hydrogenation resulted in the formation of the 3,5-spiroderivative 139 in good yield, through a 6-exo-trig ring closure. The resulting spiro- $\beta$-lactam 139 reacted with benzyl bromide, furnishing the 1-benzyl derivative $\mathbf{1 4 0}$ in an almost quantitative yield. Treatment of 
compound 140 with CAN led to the removal of the $p$-methoxyphenyl group, yielding the $N$-deprotected spiro$\beta$-lactam 141. ${ }^{92}$<smiles>[Z]NCCC[C@H](N)C(=O)OC</smiles>

137 $(\mathrm{Z}=\mathrm{Cbz})$<smiles>CC(=O)OC(C)C(C)[C@@H](C)[C@@]1(N)CCCN(Cc2ccccc2)C1=O</smiles>

142

(97\%)

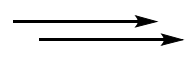

1) $\mathrm{Boc}_{2} \mathrm{O} / \mathrm{DMAP} / \mathrm{TEA}$

2) $\mathrm{DBU} / \mathrm{MeOH}$

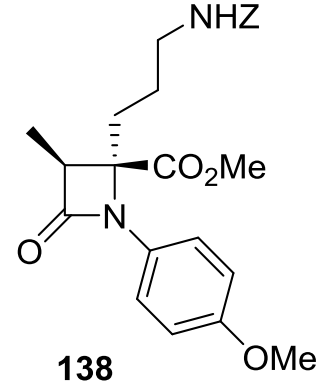

141

$(90 \%)$
$\underset{\mathrm{MeOH}}{\stackrel{\mathrm{H}_{2}, \mathrm{Pd} / \mathrm{C}}{\longrightarrow}}$
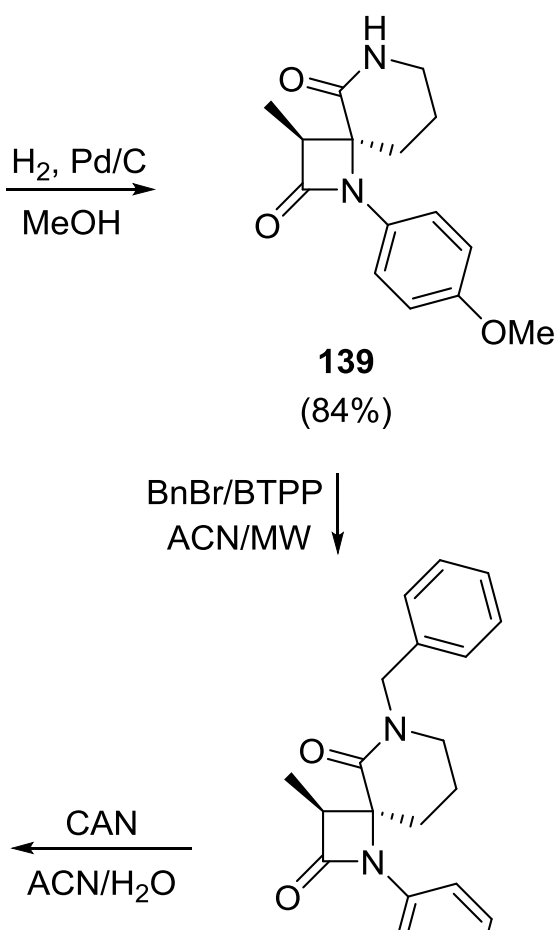

(84\%)

140

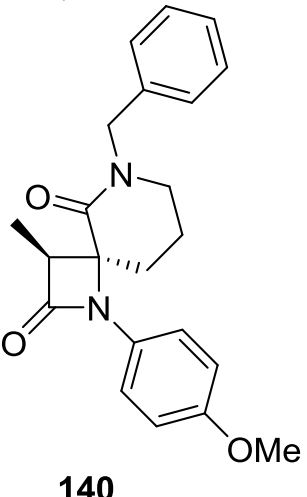

(98\%)

\section{Scheme 42}

Also relevant to this section is the fact that, during the course of preparing nylon- 3 materials bearing diverse appended functionalities, Gellman and co-workers have recently reported the ring-opening polymerization of spiro- $\beta$-lactams generating nylon-3 homo- or co-polymers. ${ }^{93}$

\subsection{Ring-transformation reactions of substituents attached to the ring carbon atoms}

Thermolysis of spiro- $\beta$-lactam-oxadiazolines 143 to generate $\beta$-lactam carbenes 144 has attracted the attention of several research groups because of the important synthetic applications of the resulting carbenes for the construction of novel mono-, spiro- or polyheterocyclic compounds. ${ }^{94}$ For example, the reaction of $\beta$ lactam carbenes 144 with 3,6-diphenyl-, 3,6-di(2-pyridyl)-, 3,6-di(2-thienyl)-, 3,6-di(4-pyridyl)-1,2,4,5tetrazines and 3,6-di-(2-pyrimidinyl)tetrazines readily afforded various aryl-fused cyclopenta[b]pyrrol-2-one derivatives in high yields. ${ }^{32,95-99}$ Recently, Wang has reported on the use of $\beta$-lactam carbenes 144 to produce a novel series of 5-triazolo[1,5-a]pyrazinepyrrol-2-ones 146 in a one-pot mechanism (Scheme 43). These 5triazolo compounds can emit light both in solution and in a solid state, with emission peaks at $77 \mathrm{~K}$ and in solid state, showing an obvious blue-shift. ${ }^{94}$ 


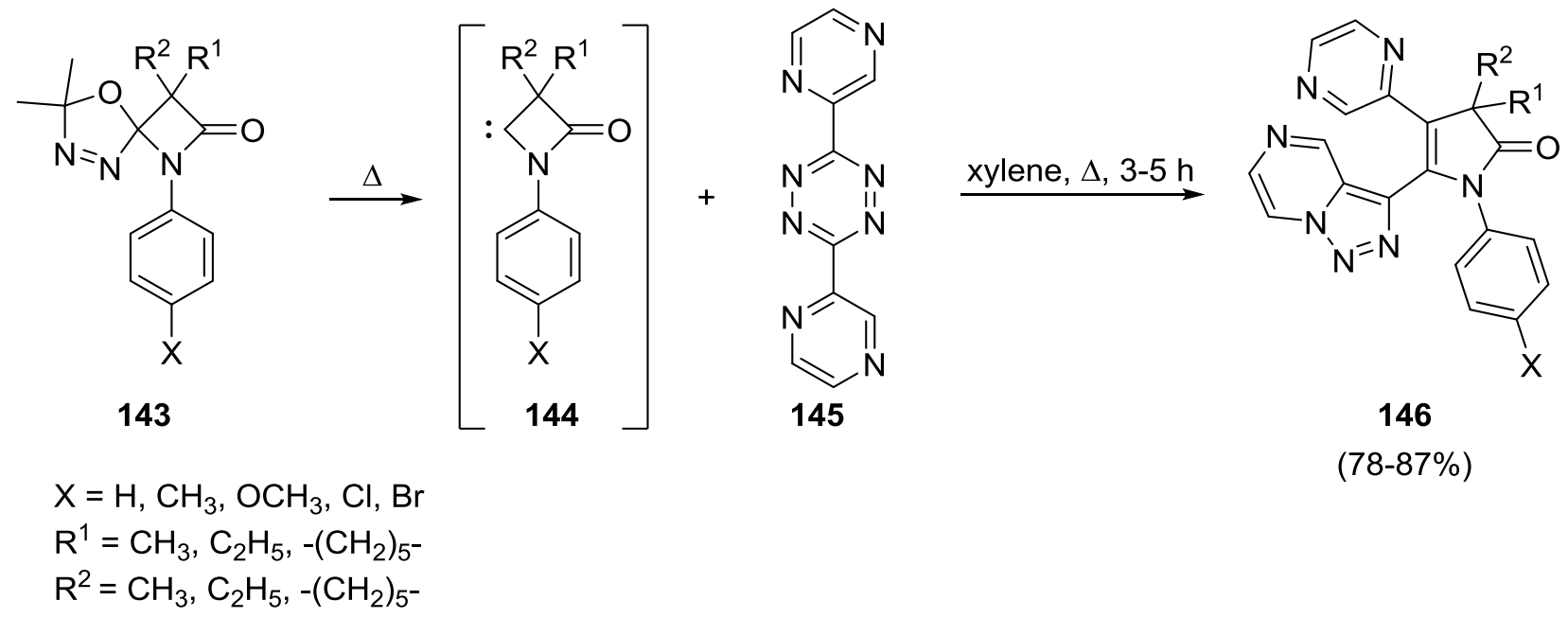

\section{Scheme 43}

The ring contraction of spiro-1-pyrazoline- $\beta$-lactams 97 via microwave-induced denitrogenation gave rise to a mixture of spirocyclopropylpenicillanates 147 and 148 (Scheme 44). ${ }^{74,75}$

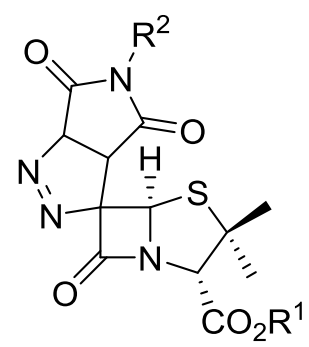

97

\section{1,2,4-trichlorobenzene $\mathrm{MW}, 250^{\circ} \mathrm{C}, 2 \mathrm{~min}$ (64-94\%)}

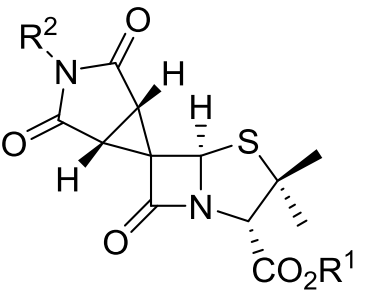

147

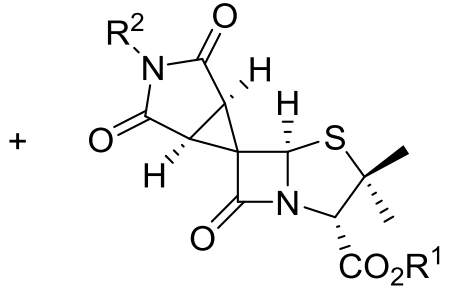

148

$$
\begin{aligned}
& \mathrm{R}^{1}=\mathrm{CHPh}_{2}, \mathrm{R}^{2}=\mathrm{Ph}, 147: 148=77: 23 \\
& \mathrm{R}^{1}=\mathrm{CHPh}_{2}, \mathrm{R}^{2}=\mathrm{CH}_{3}, 147: 148=72: 28
\end{aligned}
$$

\section{Scheme 44}

The reduction of spiro- $\beta$-lactams by different reducing reagents $\left(\mathrm{AlH} \mathrm{H}_{3}, \mathrm{AlClH} 2, \mathrm{LiAlH}_{4} \ldots\right)$ comprises one of the most convenient methodologies to generate the corresponding spirocyclic azetidines, which have been applied in drug design. ${ }^{46,48,56}$ For instance, the reduction of the amide group in compound $\mathbf{5 1}$ with $\mathrm{AlH}_{3}$ afforded spirocyclic azetidine 149 in 92\% yield (Scheme 45), which can indeed be seen as a promising building block for the preparation of complex molecules. ${ }^{48}$ Careful monitoring of the reaction is usually required to avoid reductive $\beta$-lactam ring opening.

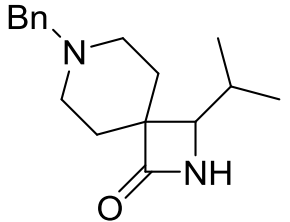

51
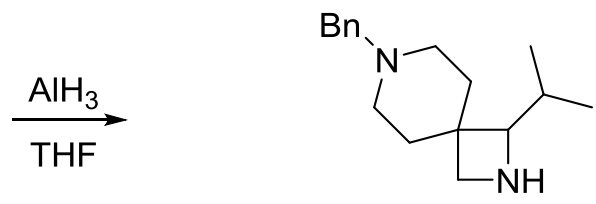

149

$(92 \%)$

\section{Scheme 45}


Furthermore, spiro- $\beta$-lactam 150 has been subjected to enolization using KHMDS in THF, and subsequent treatment of the enolate with Davis oxaziridine 151 or isoamyl nitrite led to the corresponding $\alpha$-hydroxy lactam 152 or oxime 155 in high yields, respectively (Scheme 46). Then, the $\beta$-lactams 152 and 155 were successfully reduced using monochloroalane to give spirocyclic azetidines 153 and 156, respectively. The azetidin-3-ol 153 was further converted to the corresponding ketone 154 under Swern oxidation conditions. ${ }^{100}$

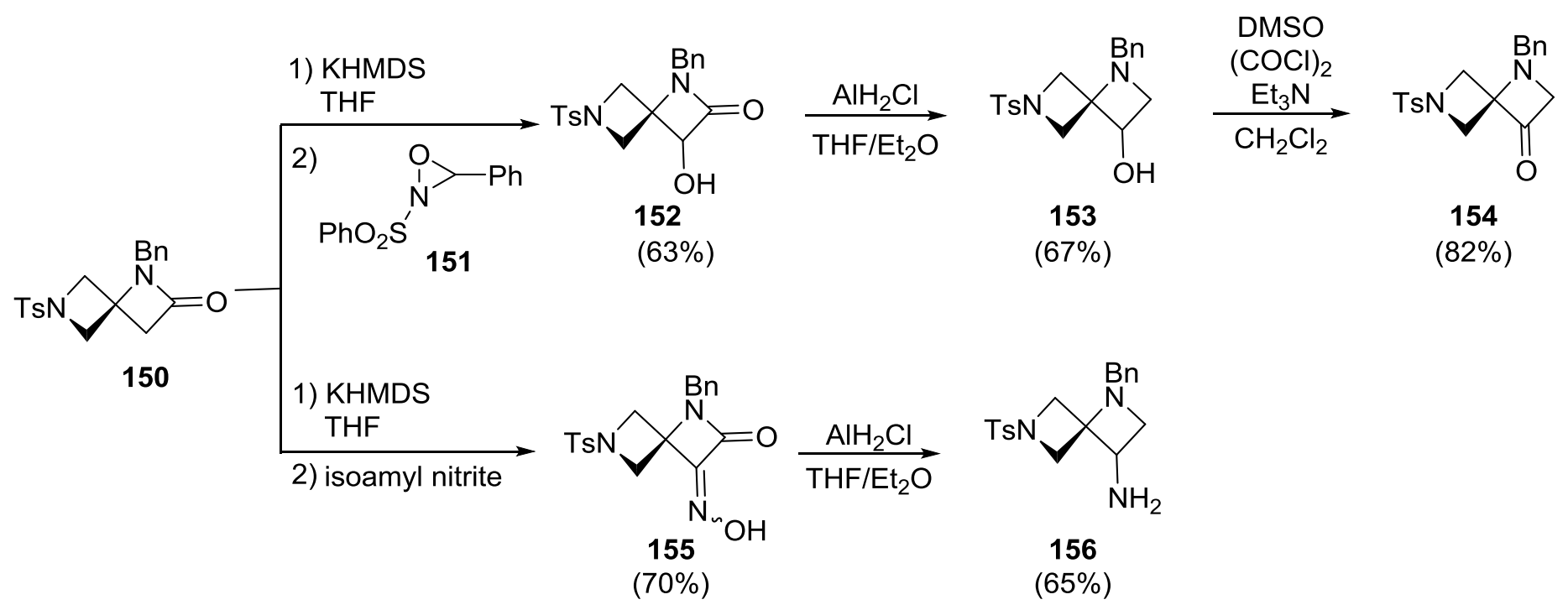

\section{Scheme 46}

\section{Bioactive Spiro-fused $\beta$-lactams}

Spiro- $\beta$-lactams constitute an interesting class of bioactive compounds possessing a wide spectrum of activities, such as antibacterial, antiviral and antimicrobial effects. In addition, the use of spiro- $\beta$-lactams as $\beta$ lactamase and cholesterol absorption inhibitors or synthetic intermediates for $\beta$-turn mimics and $\beta$-turn nucleators, has been documented. ${ }^{11-13,74,101}$ In this section, a brief selection of renewed pharmacological applications of spiro- $\beta$-lactam systems will be considered.
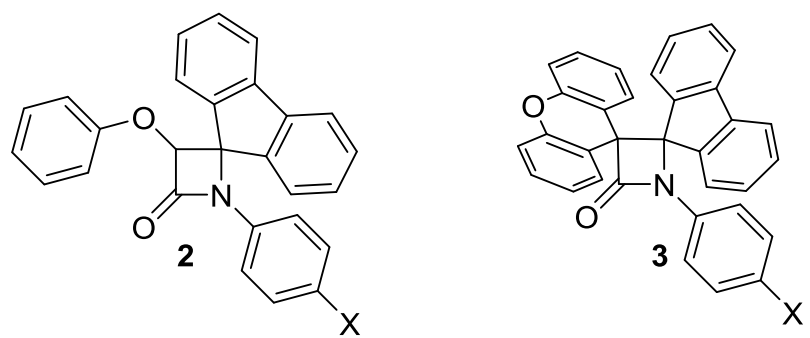

$\mathrm{X}=\mathrm{CH}_{3}, \mathrm{OCH}_{3}, \mathrm{Cl},(\mathrm{Et})_{2} \mathrm{~N}, \mathrm{OEt},(\mathrm{Me})_{2} \mathrm{~N}, \mathrm{CH}\left(\mathrm{CH}_{3}\right)_{2}$

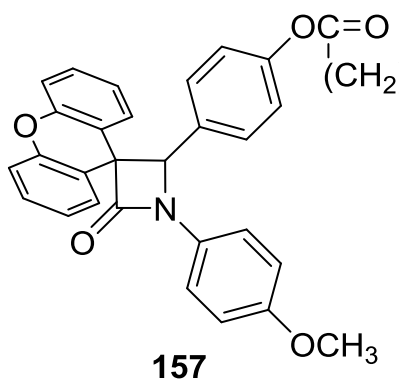<smiles>Cc1ccccc1N1C(=O)C(Cl)C12C(=O)Nc1ccccc12</smiles><smiles>CC(C)C(=O)N1CCC[C@]12CN([C@H](C(N)=O)C(=O)O)C2=O</smiles>

Figure 2. Bioactive spiro-fused $\beta$-lactams. 
The new spiro- $\beta$-lactams 2 and dispiro- $\beta$-lactams 3 have been demonstrated to exhibit good to excellent antimalarial activities against chloroquine-resistant Plasmodium falciparum K14 strain with IC 50 varying from 5 to $32.2 \mathrm{mM}^{14}$ The spirocyclic $\beta$-lactam 157 (Figure 2), supported on superparamagnetic $\mathrm{Fe}_{3} \mathrm{O}_{4} @ \mathrm{SiO}_{2}$ nanoparticles, enhanced the antibacterial activity in comparison with the corresponding spirocyclic $\beta$-lactam, which was supposed to be due to the synergic effect of the $\mathrm{Fe}_{3} \mathrm{O}_{4} @ \mathrm{SiO}_{2} / \beta$-lactam combination. ${ }^{102,103}$

A number of novel spiro[azetidine-2,3'-indole]-2',4(1'H)-dione derivatives have been tested for anti-breast cancer activity, however, only 3-chloro-1-(o-tolyl)spiro[azetidine-2,3'-indoline]-2',4-dione 158 (Figure 2) displayed a significant cytotoxicity $\left(\mathrm{IC}_{50}=22.75-25.18 \mu \mathrm{M}\right)$ for breast cancer cell lines after $48 \mathrm{~h}$, which is comparable to the standard control drug doxorubicin. ${ }^{104}$

Recently, ((2S,3R)-3-hydroxy-2-((R)-5-isobutyryl-1-oxo-2,5-diazaspiro[3.4]octan-2-yl)butanamide) 159 (Figure 2) has been examined for in vitro and in vivo pharmalogical properties. This compound appeared to be a novel $\mathrm{N}$-methyl-D-aspartate (NMDA) receptor-specific modulator that facilitates synaptic plasticity and has therapeutic potential for a variety of NMDA receptor-mediated central nervous system (CNS) disorders. ${ }^{105,106}$

\section{Conclusions}

In conclusion, the potential pharmacological activities, along with significant synthetic applications of spirocyclic $\beta$-lactams, have given a fresh impetus to synthetic chemists to design novel spiro- $\beta$-lactam structures. Synthetic approaches toward spirocyclic $\beta$-lactams, including the Staudinger ketene-imine cyclocondensation, the cyclization of $\beta$-amino acids and $\beta$-functionalised amides and transformation reactions, have been improved in recent years (e.g., increase yield and stereoselectivity of reactions as well as the use of greener reaction conditions) and have been intensively discussed in this review. In view of their interesting chemical and biological properties, spirocyclic $\beta$-lactams are expected to attract considerable attention in the future as well.

\section{Acknowledgements}

The authors are indebted to Ghent University, Belgium (Special Research Fund, BOF) for financial support.

\section{References}

1 Kumar, Y.; Singh, P.; Bhargava, G. RSC Adv. 2016, 6, 9922.

https://doi.org/10.1039/C6RA20973D

2 Alcaide, B.; Almendros, P.; Aragoncillo, C. Chem. Rev. 2007, 107, 4437.

https://doi.org/10.1021/cr0307300

3 Ojima, I. J. Org. Chem. 2013, 78, 6358.

https://doi.org/10.1021/jo400301u

4 Singh, G. S.; Sudheesh, S. Arkivoc 2014, (i), 337.

http://dx.doi.org/10.3998/ark.5550190.p009.524

5 Bhalla, A.; Bari, S. S.; Bhalla, J. In Beta-Lactams: Novel Synthetic Pathways and Applications; Banik, B. K. Ed.; Springer International Publishing: Cham, Switzerland, 2017; p 1.

6 Pitts, C. R.; Lectka, T. Chem. Rev. 2014, 114, 7930.

https://doi.org/10.1021/cr4005549 
7 Docquier, J.-D.; Mangani, S. Drug Resist. Updat. 2018, 36, 13.

https://doi.org/10.1016/j.drup.2017.11.002

8 Van den Akker, F.; Bonomo, R. A. Front Microbiol 2018, 9.

9 Vardakas, K. Z.; Kalimeris, G. D.; Triarides, N. A.; Falagas, M. E. Expert Opin. Drug Saf. 2018, $17,499$. https://doi.org/10.1080/14740338.2018.1462334

10 Abdellaoui, H.; Xu, J. Tetrahedron 2014, 70, 4323.

https://doi.org/10.1016/i.tet.2014.05.008

11 Alcaide, B.; Almendros, P. In Heterocyclic Scaffolds I: $\beta$-Lactams; Banik, B. K. Eds.; Springer Berlin Heidelberg: Berlin, Heidelberg, 2010; $p 1$.

12 Bari, S. S.; Bhalla, A. In Heterocyclic Scaffolds I: $\beta$-Lactams; Banik, B. K. Eds.; Springer: Berlin, Heidelberg, 2010; p 49.

https://doi.org/10.1007/7081 20098

13 Singh, G. S.; D’hooghe, M.; De Kimpe, N. Tetrahedron 2011, 67, 1989.

https://doi.org/10.1016/i.tet.2011.01.013

14 Jarrahpour, A.; Ebrahimi, E.; De Clercq, E.; Sinou, V.; Latour, C.; Djouhri Bouktab, L.; Brunel, J. M.

Tetrahedron 2011, 67, 8699.

https://doi.org/10.1016/i.tet.2011.09.041

15 Zarei, M.; Jarrahpour, A.; Ebrahimi, E.; Aye, M.; Torabi Badrabady, S. A. Tetrahedron 2012, $68,5505$. https://doi.org/10.1016/i.tet.2012.04.088

16 Ameri Rad, J.; Jarrahpour, A.; Ersanlı, C. C.; Atioğlu, Z.; Akkurt, M.; Turos, E. Tetrahedron 2017, $73,1135$. https://doi.org/10.1016/j.tet.2017.01.009

17 Elkanzi, N. A. A. Int. J. Org. Chem. 2012, 2, 352.

https://doi.org/10.4236/ijoc.2012.24048

18 Renuka, J.; Kanti, S.; Deepak, K. J. Heterocycl. Chem. 2013, 50, 315. https://doi.org/10.1002/ihet.1071

19 Zhang, H.-M.; Gao, Z.-H.; Ye, S. Org. Lett. 2014, 16, 3079. https://doi.org/10.1021/ol501205v

20 Rainoldi, G.; Faltracco, M.; Lo Presti, L.; Silvani, A.; Lesma, G. Chem. Commun. 2016, 52, 11575. https://doi.org/10.1039/C6CC05838H

21 Shah, R. J.; Modi, N. R.; Patel, M. J.; Patel, L. J.; Chauhan, B. F.; Patel, M. M. Med. Chem. Res. 2011, 20, 587.

https://doi.org/10.1007/s00044-010-9354-x

22 Subba Reddy, B. V.; Karthik, G.; Rajasekaran, T.; Antony, A.; Sridhar, B. Tetrahedron Lett. 2012, 53, 2396. https://doi.org/10.1016/j.tetlet.2012.02.106

23 Kandile, N. G.; Mohamed, M. I.; Ismaeel, H. M. J. Enzyme Inhib. Med. Chem. 2017, 32, 119. https://doi.org/10.1080/14756366.2016.1238365

24 Xu, J.; Yuan, S.; Peng, J.; Miao, M.; Chen, Z.; Ren, H. Chem. Commun. 2017, 53, 3430. https://doi.org/10.1039/C7CC01232B

25 Toyoda, Y.; Ninomiya, M.; Ebihara, M.; Koketsu, M. Org. Biomol. Chem. 2013, 11, 2652. https://doi.org/10.1039/c3ob00073g

26 Lauro, F.-V.; Francisco, D.-C.; Elodia, G.-C.; Eduardo, P.-G.; Maria, L.-R.; Marcela, R.-N.; Lenin, H.-H.; Bety, S.-A. Steroids 2015, 93, 8.

https://doi.org/10.1016/i.steroids.2014.09.003

27 Soleiman, H. A.; Khalafallah, A. K.; Abd-Ellatif, H. a. Eur. J. Chem. 2012, 3, 287. 
https://doi.org/10.5155/eurjchem.3.3.287-292.611

28 Anand, N.; Shah, B. A.; Kapoor, M.; Parshad, R.; Sharma, R. L.; Hundal, M. S.; Pannu, A. P. S.; Bharatam, P. V.; Taneja, S. C. J. Org. Chem. 2011, 76, 5999.

https://doi.org/10.1021/jo200363x

29 Song, J.-H.; Kwon, Y.-G.; Lee, H.-O.; Jung, D.-I.; Hahn, J.-T. J. Korean Chem. Soc. 2014, 35, 3651.

30 Reddy, D. R. S.; Risy, N. J. Pharma Chemica 2013, 5, 235.

31 Ali Ahmed Elkanzi, N.; Abdallah Abd El-Monem Yosef, H.; Mahmoud Morsy Mohamed, N. Eur. J. Chem.

2013, 4, 195.

https://doi.org/10.5155/eurjchem.4.3.195-202.777

32 Li, Y.-J.; Yan, C.-X.; Sun, Z.-X.; Cheng, Y. Aust. J. Chem. 2012, 65, 417. https://doi.org/10.1071/CH12046

33 Allen, A. D.; Tidwell, T. T. Chem. Rev. 2013, 113, 7287.

https://doi.org/10.1021/cr3005263

34 Singh, P.; Samanta, K.; Das, S. K.; Panda, G. Org. Biomol. Chem. 2014, 12, 6297. https://doi.org/10.1039/C4OB00943F

35 Heravi, M. M.; Talaei, B. In Advances in Heterocyclic Chemistry; Scriven, E. F. V., Ramsden, C. A. Eds.; Academic Press: Oxford, 2015; 114, p 147.

36 Zavar, S.; Zarei, M.; Saraei, M. Synth. Commun. 2016, 46, 2031. https://doi.org/10.1080/00397911.2016.1244691

37 Zarei, M. Bull. Chem. Soc. Jpn. 2012, 85, 360. https://doi.org/10.1246/bcsj.20110323

38 Zarei, M. Tetrahedron 2013, 69, 6620. https://doi.org/10.1016/i.tet.2013.05.121

39 Zarei, M. Monatsh. Chem. 2014, 145, 1495. https://doi.org/10.1007/s00706-014-1217-6

40 Zarei, M.; Salehinezhad, A. J. Chem. Res. 2015, 39, 698. https://doi.org/10.3184/174751915X14473416848163

41 Esmaeilpour, M.; Sardarian, A. R.; Jarrahpour, A.; Ebrahimi, E.; Javidi, J. RSC Adv. 2016, 6, 43376. https://doi.org/10.1039/C6RA03634A

42 Zarei, M.; Maaqooli, F. Synth. Commun. 2016, 46, 523. https://doi.org/10.1080/00397911.2016.1148165

43 Zavar, S.; Zarei, M.; Saraei, M. J. Chem. Res. 2016, 40, 532. https://doi.org/10.3184/174751916X14683354026584

44 Çelik, Í.; Akkurt, M.; Jarrahpour, A.; Heiran, R.; Özdemir, N. Acta Cryst. E 2014, 70, 369. https://doi.org/10.1107/S160053681400419X

45 Cremonesi, G.; Dalla Croce, P.; Forni, A.; La Rosa, C. Tetrahedron 2013, 69, 1175. https://doi.org/10.1016/i.tet.2012.11.048

46 Karlsson, S.; Bergman, R.; Löfberg, C.; Moore, P. R.; Pontén, F.; Tholander, J.; Sörensen, H. Org. Process Res. Dev. 2015, 19, 2067.

https://doi.org/10.1021/acs.oprd.5b00319

47 Kirichok, A. A.; Shton, I.; Kliachyna, M.; Pishel, I.; Mykhailiuk, P. K. Angew. Chem. Int. Ed. 2017, $56,8865$. https://doi.org/10.1002/anie.201703801

48 Kirichok, A. A.; Shton, I. O.; Pishel, I. M.; Zozulya, S. A.; Borysko, P. O.; Kubyshkin, V.; Zaporozhets, O. A.; Tolmachev, A. A.; Mykhailiuk, P. K. Chem. Eur. J. 2018, 24, 5444. 
https://doi.org/10.1002/chem.201800193

49 Liang, J.; Chen, J.; Du, F.; Zeng, X.; Li, L.; Zhang, H. Org. Lett. 2009, 11, 2820. https://doi.org/10.1021/ol901005x

50 Xu, Z.; Huang, K.; Liu, T.; Xie, M.; Zhang, H. Chem. Commun. 2011, 47, 4923. https://doi.org/10.1039/c1cc10916b

51 Xu, Z.-X.; Tan, Y.-X.; Fu, H.-R.; Liu, J.; Zhang, J. Inorg. Chem. 2014, 53, 12199. https://doi.org/10.1021/ic501849g

52 Núñez-Villanueva, D.; Bonache, M. Á.; Infantes, L.; García-López, M. T.; Martín-Martínez, M.; GonzálezMuñiz, R. J. Org. Chem. 2011, 76, 6592.

53 Guideri, L.; Noschese, R.; Ponticelli, F. J. Heterocycl. Chem. 2012, 49, 297. https://doi.org/10.1002/jhet.823

54 Sharada, L. N.; Reddy, G. S. S.; Sammaiah, B.; Sumalatha, D. Organic Chemistry: An Indian Journal 2014, 10, 127.

55 McMaster, C.; Bream, R. N.; Grainger, R. S. Org. Biomol. Chem. 2012, 10, 4752. https://doi.org/10.1039/c2ob25434d

56 Bondada, L.; Rondla, R.; Pradere, U.; Liu, P.; Li, C.; Bobeck, D.; McBrayer, T.; Tharnish, P.; Courcambeck, J.; Halfon, P.; Whitaker, T.; Amblard, F.; Coats, S. J.; Schinazi, R. F. Bioorg. Med. Chem. Lett. 2013, 23, 6325.

https://doi.org/10.1016/i.bmcl.2013.09.068

57 Nakazaki, A.; Hara, Y.; Kajii, S.; Nishikawa, T. Heterocycles 2013, 87, 611. https://doi.org/10.3987/COM-12-12657

58 Wu, X.-S.; Zhao, Y.; Zhang, G.-W.; Ge, H.-B., Angew. Chem. Int. Ed. Engl. 2014, 126, 3780. https://doi.org/10.1002/ange.201311263

59 Wu, X.-S.; Zhao, Y.; Ge, H.-B., Chem. Eur. J. 2014, 20, 9530. https://doi.org/10.1002/chem.201403356

60 Zhen, W.; Ni, J.-Z.; Yoichiro, K.; Motomu, K. Angew. Chem. Int. Ed. 2014, 53, 3496. https://doi.org/10.1002/anie.201311105

61 Wang, C.; Yang, Y.; Qin, D.; He, Z.; You, J. J. Org. Chem. 2015, 80, 8424. https://doi.org/10.1021/acs.joc.5b01302

62 Wu, X.; Yang, K.; Zhao, Y.; Sun, H.; Li, G.; Ge, H. Nat. Commun. 2015, 6, 6462. https://doi.org/10.1038/ncomms7462

63 Aihara, Y.; Chatani, N. ACS Catal. 2016, 6, 4323. https://doi.org/10.1021/acscatal.6b00964

64 Gomes F. R., L.; Veiros F., L.; Maulide, N.; Afonso A. M., C. Chem. Eur. J. 2015, 21, 1449. https://doi.org/10.1002/chem.201404990

65 Kumarasamy, E.; Ayitou, A. J.-L.; Vallavoju, N.; Raghunathan, R.; Iyer, A.; Clay, A.; Kandappa, S. K.; Sivaguru, J. Acc. Chem. Res. 2016, 49, 2713.

https://doi.org/10.1021/acs.accounts.6b00357

66 Nandini, V.; Avadakkam, S.; J.-L., A. A.; Steffen, J.; B., S. R.; Jayaraman, S. Chem. Eur. J. 2016, $22,11339$.

67 Zhu, L.; Xiong, Y.; Li, C. J. Org. Chem. 2015, 80, 628. https://doi.org/10.1021/j0502265a

68 Cai, S.; Yang, K.; Wang, D. Z. Org. Lett. 2014, 16, 2606. https://doi.org/10.1021/ol501071k

69 Baudoin, O. Acc. Chem. Res. 2017, 50, 1114. 
https://doi.org/10.1021/acs.accounts.7b00099

70 He, J.; Wasa, M.; Chan, K. S. L.; Shao, Q.; Yu, J.-Q. Chem. Rev. 2017, 117, 8754.

https://doi.org/10.1021/acs.chemrev.6b00622

71 David, D.; Ronan, R.; Olivier, B. Angew. Chem. Int. Ed. 2017, 56, 7218.

https://doi.org/10.1002/anie.201703109

72 Alcaide, B.; Almendros, P.; Luna, A.; Gómez-Campillos, G.; Torres, M. R. J. Org. Chem. 2012, 77, 3549. https://doi.org/10.1021/jo202495z

73 Alcaide, B.; Almendros, P.; Aragoncillo, C.; Callejo, R.; Ruiz, M. P.; Torres, M. R. J. Org. Chem. 2012, 77, 6917.

https://doi.org/10.1021/jo301113g

74 Santos, B. S.; Nunes, S. C. C.; Pais, A. A. C. C.; Pinho e Melo, T. M. V. D. Tetrahedron 2012, 68, 3729. https://doi.org/10.1016/i.tet.2012.03.022

75 Santos, B. S.; Gomes, C. S. B.; Pinho e Melo, T. M. V. D. Tetrahedron 2014, 70, 3812.

https://doi.org/10.1016/i.tet.2014.03.109

76 Aman, B.; Paloth, V.; Bari, S. S. Eur. J. Org. Chem. 2006, 2006, 4943.

77 Bhalla, A.; Venugopalan, P.; Bhasin, K. K.; Bari, S. S. Tetrahedron 2007, 63, 3195.

https://doi.org/10.1016/i.tet.2007.02.001

78 Moody, C. L.; Franckevičius, V.; Drouhin, P.; Klein, J. E. M. N.; Taylor, R. J. K. Tetrahedron Lett. 2012, 53, 1897.

https://doi.org/10.1016/i.tetlet.2012.01.120

79 Reshma; Arora, R.; Hundal, G.; Bhalla, A.; Bari, S. S. J. Chem. Sci. 2015, 127, 1957.

80 Bhalla, A.; Bari, S. S.; Bhalla, J.; Khullar, S.; Mandal, S. Tetrahedron Lett. 2016, 57, 2822. https://doi.org/10.1016/j.tetlet.2016.05.047

81 Narula, D.; Bari, S. S.; Banik, B. K.; Bhalla, A. Asian J Chem 2017, 29, 2582. https://doi.org/10.14233/ajchem.2017.20673

82 Wang, X.-M.; Meng, F.-Y.; Yan, W.; Han, Z.-B.; Chen, Y.-J.; Liu, L.; Wang, Z.; Ding, K.L. Angew. Chem. Int. Ed. 2012, 51, 9276.

https://doi.org/10.1002/anie.201204925

83 Dao Thi, H.; Danneels, B.; Desmet, T.; Van Hecke, K.; Van Nguyen, T.; D'hooghe, M. Asian J. Org. Chem. 2016, 5, 1480.

https://doi.org/10.1002/ajoc.201600387

84 Dao Thi, H.; Van Nguyen, T.; D’hooghe, M. Monatsh. Chem. 2018, 149, 687. https://doi.org/10.1007/s00706-017-2134-2

85 Li, S.; Cao, W.-J.; Ma, J.-A. Synlett 2017, 28, 673.

86 Isoda, M.; Sato, K.; Funakoshi, M.; Omura, K.; Tarui, A.; Omote, M.; Ando, A. J. Org. Chem. 2015, 80, 8398.

https://doi.org/10.1021/acs.joc.5b01233

87 Willcox, D.; Chappell, B. G. N.; Hogg, K. F.; Calleja, J.; Smalley, A. P.; Gaunt, M. J. Science 2016, $354,851$. https://doi.org/10.1126/science.aaf9621

88 Torres, G. M.; De La Higuera Macias, M.; Quesnel, J. S.; Williams, O. P.; Yempally, V.; Bengali, A. A.; Arndtsen, B. A. J. Org. Chem. 2016, 81, 12106.

https://doi.org/10.1021/acs.joc.6b02405

89 Shu, T.; Zhao, L.; Li, S.; Chen, X.-Y.; von Essen, C.; Rissanen, K.; Enders, D. Angew. Chem. Int. Ed. 2018, 57, 10985. 
https://doi.org/10.1002/anie.201806931

90 Singh, G. S.; Luntha, P. M. J. Heterocycl. Chem. 2011, 48, 1312.

https://doi.org/10.1002/jhet.731

91 Hu, Y.; Fu, X.; Barry, B.-D.; Bi, X.; Dong, D. Chem. Commun. 2012, 48, 690. https://doi.org/10.1039/C1CC15881C

92 Nunez-Villanueva, D.; Garcia-Lopez, M. T.; Martin-Martinez, M.; Gonzalez-Muniz, R. Org. Biomol. Chem. 2015, 13, 5195.

https://doi.org/10.1039/C50B00429B

93 Zhang, J.; Markiewicz, M. J.; Weisblum, B.; Stahl, S. S.; Gellman, S. H. ACS Macro Lett. 2012, 1, 714. https://doi.org/10.1021/mz300172y

94 Miao, X.; Yingkai, S.; Yan, Z.; Sanxiao, Z.; Jie, J.; Xiaorong, W. ChemistrySelect 2017, 2, 1370. https://doi.org/10.1002/slct.201601503

95 Shao, N.; Pang, G.-X.; Yan, C.-X.; Shi, G.-F.; Cheng, Y. J. Org. Chem. 2011, 76, 7458. https://doi.org/10.1021/jo201273p

96 Xing, J.; Wang, X.-R.; Yan, C.-X.; Cheng, Y. J. Org. Chem. 2011, 76, 4746. https://doi.org/10.1021/jo200499u

97 Wang, X.-R.; Xing, J.; Yan, C.-X.; Cheng, Y. Org. Biomol. Chem. 2012, 10, 970. https://doi.org/10.1039/C10B06595E

98 Yan, C.-X.; Zhao, Y.; Wang, X.-R.; Cheng, Y. Tetrahedron 2013, 69, 10279. https://doi.org/10.1016/j.tet.2013.10.034

99 Yao, X.; Wang, X. Arkivoc 2016, (iii), 352. http://dx.doi.org/10.3998/ark.5550190.p009.524

100 Burkhard, J. A.; Guérot, C.; Knust, H.; Carreira, E. M. Org. Lett. 2012, 14, 66. https://doi.org/10.1021/ol2028459

101 Bhattacharya, B.; Turos, E. Tetrahedron 2012, 68, 10665. https://doi.org/10.1016/i.tet.2012.06.012

102 Esmaeilpour, M.; Sardarian, A. R.; Jarrahpour, A.; Ebrahimi, E.; Javidi, J. RSC Advances 2016, 6, 43376. https://doi.org/10.1039/C6RA03634A

103 Bhalla, A.; Modi, G.; Bari, S. S.; Kumari, A.; Berry, S.; Hundal, G. Tetrahedron Lett. 2017, 58, 1160. https://doi.org/10.1016/i.tetlet.2017.02.011

104 Sukhramani, P. S.; Sukhramani, P. S.; Tirthani, S. R.; Desai, S. A.; Suthar, M. P. Pharmacia Lettre 2011, 3, 236.

105 Bittermann, H.; Gmeiner, P. J. Org. Chem. 2006, 71, 97. https://doi.org/10.1021/jo0517287

106 Amin, K. M.; Houck, D. R.; Gross, A. L.; Zhang, X.-I.; Cearley, C.; Madsen, T. M.; Kroes, R. A.; Stanton, P. K.; Burgdorf, J.; Moskal, J. R. Int. J. Neuropsychopharmacol. 2018, 21, 242.

https://doi.org/10.1093/ijnp/pyx096 


\section{Authors' Biographies}

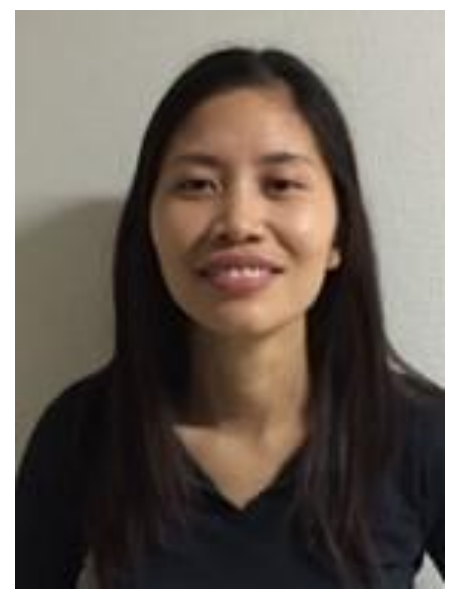

Hang Dao Thi was born in 1987 in Hai Duong (Vietnam). She obtained a Master degree in Chemical Sciences at Rennes I University (France) in 2011. Her Master thesis concerned the isolation of low polar chemical composition of the hexane fraction from Stereocaulon philipinense (Stereocaulaceae) using different methods. Recently, she obtained her PhD degree at the Department of Green Chemistry and Technology at Ghent University (Belgium) under the guidance of Prof. Matthias D'hooghe. Her PhD research focused on the synthesis and synthetic application of $\mathrm{CF}_{3}$-substituted $\beta$-lactams for the construction of biologically active $\mathrm{CF}_{3}$-substituted mono- and spirocyclic azaheterocycles.

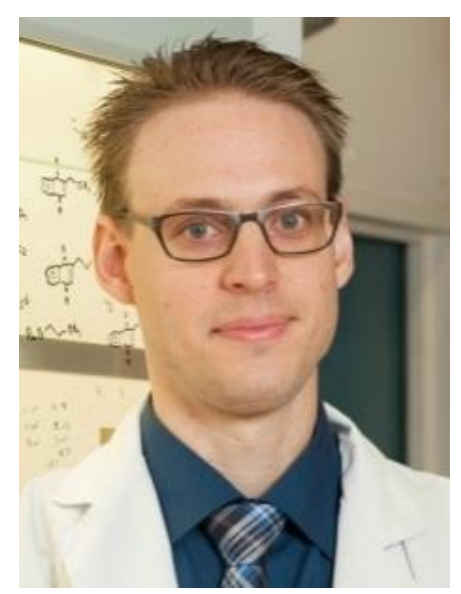

Matthias D'hooghe was born in Kortrijk, Belgium, in 1978. He received a Master degree in 2001 (Master of Science in Bioscience Engineering: Chemistry) and a PhD degree in 2006 (Doctor in Applied Biological Sciences: Chemistry), both from Ghent University, Belgium, with Prof. N. De Kimpe as promoter. In 2007, he became postdoctoral assistant at the Department of Green Chemistry and Technology, Faculty of Bioscience Engineering, Ghent University, and in 2009 he performed a short postdoctoral stay with Prof. D. Vogt at Eindhoven University of Technology (The Netherlands) in the field of homogeneous catalysis. In October 2010, he was promoted to Professor (Research Professor) at the Department of Green Chemistry and Technology (Ghent University), and he was granted tenure in 2015. His main research interests include the chemistry of small-ring azaheterocycles, with a special focus on aziridines, azetidines and $\beta$-lactams, and the synthesis of different classes of bioactive heterocyclic compounds. Prof. D'hooghe has been elected as a laureate of the DSM Science \& Technology Awards 2007, finalist of the European Young Chemist Award 2012 and recipient of the Thieme Chemistry Journal Award 2013. He is the author of $>150$ publications in international peer-reviewed journals. 